\title{
PELAS ASAS DE HERMES: A INTERVENÇÃO DO AMICUS CURIAE, UM TERCEIRO ESPECIAL*
}

\author{
ANTONIO DO PASSO CABRAL**
}

1. I ntrodução. Processo, participação e argumentação -2 . Origens $e$ previsão normativa do "amicus curiae" no ordenamento brasileiro - 3. Caracteristicas do instituto. Pode o "amicus curiae" ser considerado modalidade de intervenção de terceiros? - 4. Diferenças entre a intervenção de terceiros típica e a intervenção do amicus curiae - 5. O "amicus curiae": a intervenção pelo "interesse público" - 5.1 Fundamentos da aplicação do instituto em casos de interesse público: democracia participativa e colaboração para a justa decisão - 5.1.1 $O$ interesse em participar: aporte democrático. Análise do interesse público nas intervençōes como "amicus curiae" da CVM, do Cade, da União Federal e de entidades no processo administrativo - 5.1.2 A colaboração como imperativo juridico do contraditório - 5.2. Conceito de interesse público - 6. 0 "amicus curiae" $e$ o "Vertreter des öffentlichen Interesses": o representante do interesse público no processo administrativo na Alemanha e no Brasil 7. Posição dos Tribunais Superiores brasileiros sobre o "amicus curiae" - 8. Conclusāo. Hermes o mensageiro comunicativo - 9. Bibliografia.

\section{Introdução. Processo, participação e argumentação}

A palavra hermenêutica guarda sua origem etimológica no deus grego Hermes, divindade associada à comunicação, correspondente a Mercúrio na mitologia romana. Seu nome tem origem, segundo os historiadores, na palavra grega "herma", que designava os montes de pedra usados para indicar os caminhos. A idéia de guia

* Gostaríamos de agradecer ao colega Carlos Bruno Ferreira da Silva, pelas valiosas sugestões e revisão do texto, e à estudante Juliana Nicolau, que realizou pesquisa auxiliando a coleta de dados para o presente estudo.

** Defensor Público no Estado do Rio de Janeiro. Mestrando em Direito Público na UERJ. 
passou, no latim tardio, à associação do verbo grego "hermeneuein" com a atividade hermeneutica e correspondeu nos idiomas de origem latina a sinônimo de "interpretar". Filho de Zeus com a ninfa Maia, Hermes foi o inventor da lira e teve muitas incumbências: incentivador do comércio, protetor das estradas e dos viajantes, era o mensageiro dos deuses e trajava um capacete e sandálias aladas, que o permitiam voar em velocidade maior que a do vento; portava ainda um caduceu de ouro (bastão mágico), com duas serpentes enroladas, que tinha o poder de adormecer as pessoas.

No direito, a idéia de que a atividade hermenêutica consiste em revelar o real conteúdo da norma e fornecer um "caminho" para a decisão remonta certamente às origens gregas do termo. Nos tempos modernos, se o direito está longe de guardar características divinas, e por vezes nem mesmo desperta qualquer fé nos indivíduos, uma figura portadora de informações relevantes para a interpretação judicial, principalmente na colheita de elementos para o ato decisório, é o amicus curiae, instituto objeto do presente estudo e que vem ganhando destaque no Brasil.

No campo do direito processual, a progressiva referência e preocupação com o amicus curiae é devida à concepção publicista da jurisdição que dominou a doutrina nos últimos tempos. Admitindo o processo como ramo do direito público, identifica-se no exercício da jurisdição a busca do Estado em realizar objetivos que são seus e que precedem os interesses das partes envolvidas: objetivos sociais - educação social e pacificação de conflitos - e políticos, no sentido de preservar as liberdades públicas, afirmar o poder estatal e assegurar a participação popular através do processo. ${ }^{1}$

Dentre os escopos políticos do processo destaca-se a missão de permitir a participação do indivíduo na vida política do país. Trata-se de peculiar espectro da condição de cidadão, o status ativae civitatis, que consubstancia o direito fundamental de participação ativa nos procedimentos estatais decisórios, vale dizer, direito de influenciar a formação de normas jurídicas vinculativas. ${ }^{2}$

De fato, a participação democrática não existe somente no âmbito legislativo, através da iniciativa popular de leis, plebiscito, referendo e do direito de votar e ser votado. Qualquer meio de pressionar, influenciar e reivindicar as decisões estatais deve ser fomentado como forma legítima de participação (seja em abstrato, seja em concreto, através dos Poderes Executivo e Judiciário). Na ação popular, o cidadão atua fiscalizando e controlando a moralidade pública, os atos lesivos ao patrimônio público, meio ambiente, e outros. Também os mecanismos das ações coletivas, que podem ser manejadas por associações, encorajam, através do Judiciário, a denúncia e reivindicação da melhoria dos serviços públicos e a proteção do patrimônio histórico, artístico e cultural. Em suma, fornece o processo instrumentos para que a

1 DINAMARCO, Cândido Rangel. A Instrumentalidade do Processo. São Paulo: Malheiros, $9^{a}$ Ed., 2001, pp. 80-81.

2 Neste sentido, CALMON DE PASSOS, José Joaquim. "Instrumentalidade do processo e devido processo legal”, in Revista Forense, vol.351, p.109, preferindo a denominação, também adotada por HÄBERLE, de status ativus processualis. 
sociedade civil contribua para a definição dos rumos políticos da nação, “institucionalizando-os". 3

Quando movimentada a jurisdição por associações ou órgãos estatais incumbidos de proteger o interesse público, diz-se que a participação do indivíduo ocorre de forma indireta, através de instituições "intermediárias" (que se apresentam como anteparo entre indivíduo e Estado, como as associações) ou entidades propriamente estatais (como o Ministério Público), que recebem reivindicações dos particulares e podem pleitear em juízo as medidas cabíveis. ${ }^{4}$

Ainda se pode mencionar a participação do indivíduo não como parte no processo, mas prestando serviços e realizando funções relevantes para a atividade judicial, na condição de perito, juiz leigo e conciliador no procedimento dos juizados especiais, da função de jurado nos procedimentos do Tribunal do Júri etc.

$\mathrm{Na}$ esteira da concepção publicista da jurisdição, o processo deve representar, por conseguinte, outro cenário de debate público, mais um canal de desenvolvimento da democracia participativa, instrumento também de ação política, palco para os mensageiros populares que, inspirados em Hermes, exercitem nos autos a argumentação com o fim de colaborar para o resultado decisório.

José Joaquim Calmon de Passos leciona, com propriedade:

"Acredito estejamos caminhando para o processo como instrumento político de participação. A democratização do Estado alçou o processo à condição de garantia constitucional; a democratização da sociedade fa-lo-á instrumento de atuação política. Não se cuida de retirar do processo sua feição de garantia constitucional, sim fazê-lo ultrapassar os limites da tutela dos direitos individuais, como hoje conceituados. Cumpre proteger-se o individuo e as coletividades não só do agir 'contra legem' do Estado e dos particulares, mas de atribuir a ambos o poder de provocar o agir do Estado $e$ dos particulares no sentido de se efetivarem os objetivos politicamente definidos pela comunidade". 5

Releva, neste contexto, o instituto do amicus curiae, introduzido no ordenamento jurídico brasileiro pela Lei $6.385 / 76$ e recentemente estendido ao campo da jurisdição constitucional pela Lei $9.868 / 99$, que disciplinou o procedimento das ações diretas de inconstitucionalidade e ações declaratórias de constitucionalidade no Supremo Tribunal Federal. O amicus curiae, como se verá, representa um potente mecanismo para tornar real este ideário de transformar o processo em uma poderosa via de manifestação política.

3 MENDES, Aluisio Gonçalves de Castro. Açōes coletivas no direito comparado e nacional. São Paulo: Revista dos Tribunais, 2002, p.32, ressaltando a importância política das demandas coletivas em provocar o Estado-juiz a pronunciar-se sobre questōes de grande relevância na sociedade.

4 DINAMARCO, Cândido Rangel. A Instrumentalidade do Processo. Op.cit., p.173.

5 CALMON DE PASSOS, José Joaquim. "Democracia, participação e processo", in Pellegrini, Ada et alii (Coord.) Participação e Processo. São Paulo: Revista dos Tribunais, 1988, p. 95. 
A expressão latina "amicus curiae" significa "amigo da corte" (friend of the court ou Freund des Gerichts). As origens do instituto do amicus curiae remontam ao direito romano segundo alguns autores, mas foi certamente no direito norte-americano que a figura interventiva desenvolveu-se. De fato, o sistema do common law adota o modelo do stare decisis, em que as decisões jurisprudenciais vinculam os casos semelhantes que venham a ocorrer no futuro. Assim, a força do precedente judicial pode fazer com que uma decisão proferida em relação a um litígio individual produza de algum modo efeitos a todos os futuros processos de mesma natureza. Surge então a necessidade de possibilitar que setores sociais diversos possam influenciar as decisões judiciais, ainda que não possuam interesse ou relação direta com o objeto do processo em que se manifestam. ${ }^{6}$

O fundamento do instituto, portanto, é o permissivo de manifestação de terceiros quando o caso puder afetar toda a sociedade, mesmo em processos cuja demanda seja limitada individualmente, permitindo-se que sejam trazidos ao processo elementos que sejam relevantes para a cognição do órgão julgador. ${ }^{7}$

Nos Estados Unidos, entes da Federação (como a União Federal, através do Solicitor General), sociedades e associações civis, grupos de pressão (lobby), organizações não governamentais e outras entidades utilizam-se do brief for an amicus curiae como instrumento participativo, como previsto na Rule 37 do Regimento Interno da Suprema Corte.

Com efeito, o amicus curiae ofereceu mecanismo da ampla participação social em alguns célebres casos da jurisprudência norte-americana. Durante o julgamento do caso Paterson v. McLean Credit Union, 112 entidades privadas, 47 State Attorney Generals, 66 Senadores dentre outros grupos foram admitidos como amici curiae. No caso Gideon v. Wainright, julgado em 1963, em que se discutia a constitucionalidade de um julgamento sem a assistência de advogado, mais de 20 Estados-membros da Federação e outras entidades intervieram nesta condição. Também no caso Romer $v$. Evans, em que se debatia acerca da constitucionalidade de uma lei estadual que restringia posições jurídicas de indivíduos homossexuais, a atuação de um grupo de entidades, na condição de amicus curiae, representou decisivo fator para o resultado do processo. ${ }^{8}$

6 HIRTE, Heribert. "Der amicus-curiae-brief — das amerikanische Modell und die deutschen Parallelen", in Zeitschrift für Zivilprozeâ, 104. Band, Heft 1, 1991, pp. 14-15.

7 MACIEL, Adhemar Ferreira. "Amicus curiae: um instituto democrático", in Revista de Processo, vol.106, p.281.

8 Confira-se comentário do caso em CANOTILHO, José Joaquim Gomes. “A principialização da jurisprudência através da constituição", in Revista de Processo, vol.98, pp. 87-88. Neste processo, intervieram como amici curiae as seguintes associações: The American Psychological Association, The American Psychiatric Association. The National Association of Social Workers, Inc. e a Colorado Psychological Association. Veja-se a íntegra da petição de amicus curiae em http://www.apa.org/pi/romer.html, acessado em 26.10.2003, ou em http://www.psyclaw.org/romerbrief.html, acessado em 26.10.2003. 
As peculiaridades do common law fizeram com que o instituto ganhasse tratamento em outros países que adotam o mesmo sistema, como o Canadá, onde a regra $\mathrm{n}^{\circ} 92$ do Regimento Interno da Suprema Corte permite que o tribunal ou um de seus membros possa nomear um amicus curiae. ${ }^{9}$ Também na Austrália, onde ainda há carência de sistematização do amigo da corte, existe aplicação do instituto mesmo sem previsão legal. ${ }^{10}$

No Brasil, o instituto do amicus curiae foi recentemente consagrado nos processos de controle de constitucionalidade pela Lei 9.868/99, permitindo uma efetiva manifestação social acerca das questões constitucionais, com a possível realização de audiências públicas, oitiva de peritos, apresentação de memoriais etc. Sua admissibilidade nos processos em que se desenvolve jurisdição constitucional decorre da concepção de democracia deliberativa e participativa e da extensão do conceito de intérprete da constituição.

O paradigma tradicional atribuía aos órgãos do Estado, aos agentes públicos e às partes litigantes a função de exegeta constitucional. No entanto, modernamente, o conceito de intérprete constitucional e sua extensão vem sendo repensado, a partir da constatação do pluralismo social. Sem embargo, a doutrina moderna, em especial a alemã e norte-americana, prega ser a hermenêutica constitucional um processo aberto, abrangendo toda a sociedade, que é participante desse processo, já que "a interpretação constitucional jurídica traduz a pluralidade da esfera pública e da realidade". " Para Peter Häberle, a constituição é a síntese dialética entre a norma e a realidade social concreta por ela regulada. Todos os cidadãos são também intérpretes da constituição.

Todavia, já existe, há algum tempo, previsão normativa do instituto do amigo da corte no ordenamento brasileiro. A doutrina e a jurisprudência ensinam ${ }^{12}$ que $o$

9 Diz o art.92: "Nomination d'un amicus curiae. Dans le cas d'un appel, la Cour ou un juge peut nommer un amicus curiae", íntegra disponível em http://www.scc-csc.gc.ca/, acessado em 26.10.2003.

10 HIRTE, Heribert. Op.cit., p. 24.

11 HÄBERLE, Peter. Hermenêutica Constitucional. A sociedade aberta dos intérpretes da Constituição: contribuição para a interpretação pluralista e "procedimental" da Constituição. Trad. Gilmar Ferreira Mendes. Porto Alegre: Sérgio Antonio Fabris Editora, 1997. p. 43. No mesmo sentido, MENDES, Gilmar Ferreira. "Controle de Constitucionalidade: Hermenêtutica Constitucional e Revisão de Fatos e Prognoses Legislativos pelo Órgão Judicial" in Revista dos Tribunais, vol.766, agosto, 1999. pp. 13-15

12 “Art. 31 - Nos processos judiciários que tenham por objetivo matéria incluida na competência da Comissão de Valores Mobiliários, será esta sempre intimada para, querendo, oferecer parecer ou prestar esclarecimentos, no prazo de quinze dias a contar da intimaçāo. (Incluído pela Lei $n^{\circ}$ 6.616, de 16.12.1978)." O próprio STF já corroborou este entendimento. No julgamento da Medida Cautelar na Adin. 2.130-SC (Relator: Min. Celso de Mello, DJU em 02.02.2001), afirmou o Tribunal que: "É certo que, embora inovadora em tema de controle abstrato de constitucionalidade (que faz instaurar processo de natureza marcadamente objetiva), a disciplina legal pertinente ao ingresso formal do 'amicus curiae' já se achava contemplada, desde 1976 , no art. 31 da Lei $n^{\circ} 6.385$, de 07.12.76, que permite a intervenção da Comissão de Valores Mobiliários (CVM) em processos judiciais de caráter meramente subjetivo, nos quais se discutam questões de direito societário, sujeitas, no plano administrativo, à competência dessa entidade autárquica federal." 
art.31 da Lei 6.385/76, com a redação dada pela Lei 6.616/78, previu pela primeira vez a intervenção desta natureza por parte da CVM (Comissão de Valores Imobiliários) em causas em que sejam debatidas questões que no plano administrativo incluem-se dentro das atribuições fiscalizadoras da entidade.

Posteriormente a Lei 8.197/91 (art.2 $2^{\circ}$ ) admitia a intervenção da União Federal como amicus curiae nos casos então previstos. Esta lei, depois de alterada por medida provisória, foi revogada pela Lei $9.469 / 97$, que em seu art. $5^{\circ}$ dispõe, de forma semelhante, ser possível a intervenção da União nas causas em que figurarem como parte entes da administração pública indireta. ${ }^{13}$

Também a Lei 8.884/94, na disciplina das infrações contra a ordem econômica, atribuiu ao Conselho Administrativo de Defesa Econômica (Cade) a possibilidade de intervir como amicus curiae nos processos judiciais em que a aplicação de qualquer dispositivo desta lei esteja em debate. ${ }^{14}$

$O$ instituto encontra-se presente também nos processos administrativos. A Lei 9.784/99, que regula o procedimento administrativo no âmbito federal, estabelece, em seus arts.31 e 32, que poderá o órgão competente admitir a intervenção do amicus e até realizar audiência pública para permitir debates mais amplos sobre a matéria discutida no processo.

\section{Características do instituto. Pode o "amicus curiae" ser considerado modalidade de intervenção de terceiros?}

São sujeitos do processo as pessoas entre as quais se forma a relação jurídica processual e todos aqueles que participam do processo, ainda que como auxiliares de justiça: juiz, autor, réu (partes), peritos, contadores, oficiais de justiça, advogados, membros do Ministério Público e da Defensoria Pública, todos são atores de uma ou mais árias processuais. Dentre esses sujeitos, interessam-nos as partes e os terceiros.

A ultrapassada apreensão civilista do fenômeno processual identificava as partes com os titulares da relação jurídica de direito material alegada e discutida no processo. $O$ autor era o credor e o devedor era réu. Com a constatação de que a relação jurídica processual era diversa daquela oriunda do direito material, bem como

13 “Art. $5^{\circ}$ A União poderá intervir nas causas em que figurarem, como autoras ou rés, autarquias, fundações públicas, sociedades de economia mista e empresas públicas federais. Parágrafo único. As pessoas jurídicas de direito público poderão, nas causas cuja decisão possa ter reflexos, ainda que indiretos, de natureza econômica, intervir, independentemente da demonstração de interesse jurídico, para esclarecer questões de fato e de direito, podendo juntar documentos e memoriais reputados úteis ao exame da matéria e, se for o caso, recorrer, hipótese em que, para fins de deslocamento de competência, serão consideradas partes".

14 Esta intervenção poderá ser realizada pela Procuradoria do Cade (art. $7^{\circ}, \mathrm{XV}$ ), apresentando pareceres técnicos, estudos e relatórios sobre as infrações à ordem econômica, com auxílio da Secretaria de Direito Econômico (art.14, XIV) e entidades da administração indireta (art. 36) ou de qualquer pessoa (art. 44). 
a partir do desenvolvimento da substituição processual, tal concepção foi abandonada. ${ }^{15}$

Pode-se conceituar parte, atualmente, como aquele que formula ao Estado-juiz pedido em seu nome ou em nome de outrem (autor) e aquele em face de quem a atuação estatal deverá incidir (réu), ${ }^{16}$ aquele que pede e aquele em relação a quem se pede a tutela jurisdicional. ${ }^{17} \mathrm{O}$ conceito de terceiro, todavia, não se nos apresenta ontologicamente, mas por exclusão, negação: será terceiro, todo aquele que não for parte. ${ }^{18}$

J.E. Carreira Alvim define terceiros como "as pessoas que, não sendo parte na relação processual, são pela lei legitimadas para participar dela". ${ }^{19}$ Nota-se claro enfoque na finalidade de participação. Em seguida, todavia, liga o mesmo autor a atuação do terceiro ao propósito de obter do processo "uma utilidade adicional". ${ }^{20}$

Esta utilidade na participação processual para os terceiros, destacada por alguns autores, teria aspectos diversos caso se trate de modalidade de intervenção de terceiros espontânea (quando o terceiro voluntariamente pretende ingressar na relação jurídica) ou quando for provocada, coata (forçada pela parte - não pelo juiz - e contra a vontade do terceiro, que apenas se submete a ela). ${ }^{21}$ Para os terceiros que intervêm espontaneamente, a utilidade da intervenção seria a de evitar os efeitos das decisões judiciais, alterando os resultado do processo através de sua manifestação. ${ }^{22}$ Ressalte-se que os terceiros podem ser atingidos pelos efeitos reflexos da sentença nas suas relações jurídicas de direito material e que sejam ligadas àquela discutida no litígio. ${ }^{23}$ Contudo, a autoridade da coisa julgada (que é uma qualidade da sentença, diferente de seus efeitos, como bem ressaltado por Liebman) não os possa normalmente atingir, por força do art. 472 do CPC (res inter alios judicata tertio neque nocet neque prodest) ${ }^{24}$ Quando se trata de intervenção de terceiros

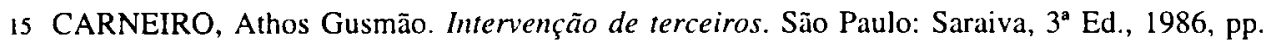
3-5.

16 Em sentido semelhante, CARREIRA ALVIM, José Eduardo. Elementos de Teoria Geral do Processo. Rio de Janeiro: Forense, 1999, p.178.

17 JAUERNIG, Othmar. . Zivilprozessrecht. München: C.H.Beck Verlag, 28 Ed., 2003, p. 57: "Partei ist, wer für sich Rechtsschutz vom Gericht begehrt und gegen wen Rechtsschutz begehrt wird, und zwar durch ein auf den Namen beider abgestelles, für und gegen sie wirkendes Urteil". Fórmula semelhante é adotada por LIEBMAN, Enrico Tullio. Manual de Direito Processual Civil. Trad. Cândido Rangel Dinamarco. Rio de Janeiro: Forense, vol. I, 1984, p. 89; DINAMARCO, Cândido Rangel. Litisconsórcio. São Paulo: Malheiros, 7^ Ed., 2002, p. 20.

18 CARNEIRO, Athos Gusmão. Op.cit., p. 45; DINAMARCO, Cândido Rangel. Litisconsórcio. Op.cit., p. 26; LIEBMAN, Enrico Tullio. Op.cit., p. 90.

19 CARREIRA ALVIM, José Eduardo. Op.cit., p. 185.

20 Idem, p. 187.

21 LIEBMAN, Enrico Tullio. Op.cit, p.110; CARNEIRO, Athos Gusmāo. Op.cit., p.53.

22 BAUR, Fritz e GRUNSKY, Wolfgang. Zivilprozeârecht. Kriftel: Luchterhand, 10. Auflage, 2000, p. 44.

23 CARNEIRO, Athos Gusmão. Op.cit., pp. 111-112.

24 KUMMER, Max. Grundriss des Zivilprozessrechts. Bern: Stämpfli, 1970, p.127: “In persönlicher Beziehung erfasst die Rechtskraft nur die Prozessparteien (...)"; Cf.CARREIRA ALVIM, José Eduardo. Op.cit., p. 302; LIEBMAN, Enrico Tullio. Op.cit., pp. 53-54; BAUR, Fritz e GRUNSKY, Wolfgang. Op.cit., pp. 210-211. 
coata ou forçada, sua utilidade para a aquele que pretende a intervenção e provoca o terceiro seria obter, no mesmo processo, título executivo que permita a instauração do processo de execução também em face deste e estenda a eficácia preclusiva da coisa julgada também aos terceiros que ingressam na relação processual, impedindo-os de discutir novamente a "justiça da decisão". 25

Aquele que atua como amicus curiae decerto não se inclui no conceito de parte pois não formula pedido, não é demandado ou tampouco titulariza a relação jurídica objeto do litígio. ${ }^{26}$ Também não exterioriza pretensão, compreendida como exigência de submissão do interesse alheio ao seu próprio, ${ }^{27}$ pois seu interesse não conflita com aquele das partes. $E$, dentro da conceituação puramente processual dos terceiros, ${ }^{28}$ devemos admitir necessariamente que o amicus curiae inclui-se nesta categoria. Sua manifestação deve ser compreendida como verdadeira modalidade de intervenção de terceiros, não obstante a disposição do art. $7^{\circ}$ da Lei $9.868 / 99$ que nega peremptoriamente o uso da intervenção de terceiros no processo da ação direta de inconstitucionalidade, cristalizando entendimento já consagrado no regimento interno do STF. Esta vedação deve ser compreendida como proibição do manejo das modalidades de intervenção previstas no CPC (arts. 50/80), o que não desconfigura o amicus curiae como espécie de intervenção de terceiros. ${ }^{29}$

Intervir tem raiz latina (inter venire) e significa "entrar no meio". Assim, toda vez que alguém ingressar em processo pendente, tal conduta reputar-se-á interventiva ${ }^{30}$ Entendemos que, diante do conceito de terceiro e da etimologia da palavra intervenção, deve ser considerada a manifestação do amicus curiae como intervenção de terceiros. ${ }^{31}$ Mas as semelhanças terminam por aí. Esta modalidade de intervenção guarda características próprias que a diferencia das formas clássicas de ingresso de

25 LIEBMAN, Enrico Tullio. Op.cit., pp.116-117.

26 Fato constantemente decidido pelo STJ no que tange à intervenção da União Federal como amicus curiae prevista na Lei $9.469 / 97$. Diz a jurisprudência que este tipo de intervenção não torna a União nem parte, nem tampouco assistente e, como seu interesse não é jurídico, não ocorre deslocamento da competência para a Justiça Federal. A questão já foi sumulada pelo Supremo Tribunal Federal (verbete $n^{\circ}$ 517) e pacificada no STJ. Cf. CARNEIRO. Athos Gusmão. "Da intervenção da União Federal como amicus curiae. llegitimidade para, nesta qualidade, requerer a suspensão dos efeitos da decisão jurisdicional. Leis $n^{\circ} 8.437 / 92$, art. $4^{\circ}$ e $\mathrm{n}^{\circ} 9.469 / 97$, art. $5^{\circ}$ ", in Revista Forense, vol.363, setembro-outubro, 2002, pp.184-188.

27 Cf. TESHEINER, José Maria Rosa. "Situações subjetivas e processo", in Revista de Processo, vol.107, pp.18 e ss.

28 Assim como o conceito de parte. Cf. JAUERNIG, Othmar. Op.cit., p.58: "Der Parteibegriff ist rein formal oder prozessual, vom materiellen Recht völlig gelöst"; DINAMARCO, Cândido Rangel. Litisconsórcio. Op.cit., p. 28; KUMMER, Max. Op.cit., p.54: “Der Begriff knüpft einfach an die äussere Tatsache na, dass einer als Kläger auftritt, ein anderer als Beklagter ins Recht gefasst wird. Er nimmt, so verstanden, keinen Bezug auf das materielle Recht".

29 No sentido do texto, PEREIRA, Milton Luiz. "Amicus curiae - Intervenção de terceiros", in Revista de Processo, vol.109, p.39. Em sentido contrário, Cf. MACIEL, Adhemar Ferreira. "Amicus curiae: um instituto democrático", Op.cit., p. 281.

30 DINAMARCO, Cândido Rangel. Litisconsórcio. Op.cit., p. 30.

31 HIRTE, Heribert. Op.cit., p. 41. 
sujeitos estranhos ao processo previstas no CPC e que ganham similares em inúmeros ordenamentos estrangeiros. $\mathrm{O}$ amigo da corte é um terceiro sui generis (ou terceiro especial, de natureza excepcional) ${ }^{32}$ e sua intervenção pode ser classificada como atipica. $^{33}$

\section{Diferenças entre a intervenção de terceiros típica e a intervenção do "amicus curiae"}

De fato, são várias as diferenças entre as modalidades clássicas de intervenção de terceiros previstas no Código de Processo Civil (que denominamos típicas) e a atuação interventiva do amicus curiae. No próximo item, buscaremos traçar um paralelo entre os dois modelos de intervenção, delineando os pontos divergentes entre ambos.

A intervenção de terceiros altera subjetivamente a relação processual, originariamente existente entre juiz, autor e réu, ora para substituí-los, ora para acrescentar-lhes outros sujeitos, que passarão a integrar a relação já existente ${ }^{34}$ ou formarão, in simultaneus processus, uma nova relação jurídica processual com uma das partes. ${ }^{35}$ A intervenção, de toda sorte, transforma o terceiro em parte do processo. ${ }^{36}$

O amicus curiae, uma vez admitida sua manifestação, não se agrega à relação processual, porque seu interesse no litígio é decorrente do direito à participação no processo. Não há interesse em integrar a relação processual, vez que o título executivo que porventura seja formado não incluirá o amigo da corte, pelo que, neste particular, seu interesse é reflexo ou mediato.

Por outro lado, o interveniente típico deve demonstrar seu interesse jurídico na demanda (rechtliches Interesse), ou seja, imperativo é que se comprove a influência que o deslinde do processo poderá ter sobre uma relação jurídica do interveniente (Rechtsbeziehung begründetes Interesse) ${ }^{37}$ Se este alegar ser titular de relação

32 PEREIRA, Milton Luiz. "Amicus curiae - Intervenção de terceiros", Op.cit., p.44.

33 Denominação de CARNEIRO. Athos Gusmão. "Da intervenção da União Federal como amicus curiae.(...)", Op.cit., p.187.

34 ARAÚJo CINTRA. Antonio Carlos et alii. Teoria Geral do Processo. Op. Cit., p. 265.

35 CARNEIRO, Athos Gusmão. Intervenção de terceiros. Op.cit., pp. 53-55, diferenciando a "intervenção por inserção" da " intervenção por ação".

36 Idem. pp. 45-47, advertindo o autor, com amparo nos ensinamentos de Hernando Echandia, que haverá outros casos de alteração subjetiva da demanda que não se configuram como intervenção de terceiros, como a sucessão processual e a citação dos litisconsortes necessários. Ademais, o assistente simples não ingressaria na qualidade de parte, pois não formula pedido ou tampouco se sujeita à pretensão de outrem. No mesmo sentido, JAUERNIG, Othmar. Op.cit., p. 345: "Der Nebenintervenient wird weder Partei noch Parteivertreter, sondern Gehilfe der Partei". Em posição contrária, outros setores doutrinários afirmam ter o assistente a qualidade de parte secundária, pois este, embora não demande ou seja demandado, tem liberdade de atuação e exerce poderes e ônus processuais idênticos aos da parte assistida. Cf. DINAMARCO, Cândido Rangel. Litisconsórcio. Op. cit., p. 23. 
jurídica de direito material incompatível com aquela que será afirmada caso uma das partes seja vencedora, haverá interesse jurídico para a intervenção. ${ }^{38}$ Não cabe um mero interesse econômico ou afetivo, tampouco a intenção de esclarecer matéria de fato ou de direito. ${ }^{39}$

O amicus curiae não precisa demonstrar interesse jurídico. Sua atuação decorre da compreensão do relevante interesse público na jurisdição e da busca de permitir a participação política através do processo. A importância de sua intervenção é política e seu interesse é ideológico, de exercer parcela de participação manifestando-se nos autos. Situação semelhante ocorre com a legitimação do denominado ideological plaintiff na litigância coletiva das class actions nos EUA, em que a parte não porta interesse jurídico mas uma conexão ideológica com um interesse da comunidade, o que representa uma forma de participação processual que é sustentada e incentivada por autores como Mauro Cappelletti e Vicenzo Vigoritti. ${ }^{40}$

De fato é próxima a atuação do amicus curiae com aquela do assistente simples e alguns setores doutrinários por vezes ressaltam um suposto "altruísmo" na intervenção assistencial. ${ }^{41}$ Todavia, ao contrário do amigo da corte, o assistente é movido verdadeiramente por interesse jurídico, que é inclusive requisito para sua intervenção não sendo acertado atribuir-lhe tal característica. ${ }^{42}$

Por outro lado, nada impede que o amigo da corte tenha um interesse, mesmo que indireto, reflexo, meramente econômico, no deslinde do processo, o que modernamente vem sendo observado em alguns países. ${ }^{43}$ Todavia, a existência deste interesse ou sua qualificação como "jurídico" não é requisito para a intervenção do amicus curiae. Cabe ressaltar, exempli gratia, que para a intervenção do amigo da corte no Canadá não se exige qualquer demonstração do interesse do amicus, o que

37 KUMMER, Max. Op.cit., p. 138; JAUERNIG, Othmar. Op.cit., pp. 344-345. Veja-se o art.50 do CPC.

38 Critério adotado por CARREIRA ALVIM, José Eduardo. Op.cit., p.185.

39 BAUR, Fritz e GRUNSKY, Wolfgang. Op.cit., p.102: "Ein nur wirtschaftliches oder ideelles Interesse genïgt nicht. Ein rechtliches Interesse ist vor allem anzunehmen in den Fällen der Rechtskrafterstreckung einer Regreßforderung oder Regreßverbindlichkeit;" HIRTE, Heribert. Op.cit., p.43; CARNEIRO, Athos Gusmão. "Mandado de Segurança - Assistência e amicus curiae", in Revista Síntese de Direito Civil e Processual Civil, n. 24, jul-ago, 2003, p. 36.

40 MENDES, Aluisio Gonçalves de Castro. Op.cit., pp.103-107.

41 Assim. LIEBMAN, Enrico Tullio. Op.cit., p.114, onde, a contrario sensu, ao mencionar as características da intervenção do assistente, assevera que "sua intervenção não é sempre altruística, não é destinada a favorecer a parte ajudada". (grifo nosso)

42 Assim, p.ex., negam a qualidade de assistente ao amicus curiae, CARNEIRO. Athos Gusmão. "Da intervenção da União Federal como amicus curiae.(...)", Op.cit., p.183; PEREIRA, Milton Luiz. "Amicus curiae - Intervenção de terceiros", Op.cit, p. 41.

43 HIRTE, Heribert. Op.cit., p.15, ipsis litteris: "Mit dieser letzten Aufgabe ist ein Funktionswandel angedeutet hin zum amicus curiae brief, wie er heute in den USA eine zentrale Rolle spielt (weniger in anderen common law Ländern). Denn wer das Gericht auf kollusives Verhalten der Parteien aufmerksam macht, nimmt notwendig Partei für die Partei, der diese Äuâerung nutzt; er wird vom neutralen 'Freund des Gerichts' zum Parteivertreter, da ihm insoweit das Mandat fehlt". 
é exigido em outras modalidades de intervenção perante o tribunal canadense. ${ }^{44} \mathrm{Na}$ Austrália, o tribunal máximo da nação, a High Court of Australia, não possui em seu regimento interno qualquer disposição acerca do amicus curiae, tratando todavia, da intervenção de pessoas que não façam parte do processo, desde que demonstrem - aqui sim, ao contrário do amigo da corte - interesse. ${ }^{45}$

No Brasil as normas previdentes do amicus curiae também desconsideram o interesse jurídico como requisito para sua intervenção, o que se observa nas manifestações em processos administrativos previstas na Lei 9.784/99, na intervenção do Cade, da CVM e da União Federal, como se verá adiante. O amigo da corte é, sem dúvida, um terceiro desinteressado no sentido jurídico.

Outra diferença crucial entre a intervenção de terceiros em geral e o amicus curiae reside nos efeitos do julgamento e da autoridade da coisa julgada sobre os terceiros. Já restou salientada a utilidade da intervenção: para o terceiro, no sentido de escapar aos efeitos reflexos da sentença; para as partes, a busca de estender aos terceiros o título executivo e a autoridade da coisa julgada que reveste o julgamento. Trata-se da denominada "eficácia da intervenção" (Interventionswirkung), por vezes confundida com a coisa julgada, mas pertinente à eficácia preclusiva dela decorrente (Präklusionswirkung), ${ }^{46}$ que impede que o terceiro discuta a matéria já debatida em outro processo, "a justiça da decisão", na dicção do art.55 CPC, dispositivo com previsão análoga em outras legislações, como no $\S 68$ da Zivilprozessordnung alemã. ${ }^{47} \mathrm{O}$ amicus curiae não se sujeita a esta peculiar preclusão resultante da coisa julgada, podendo livremente discutir a matéria que motivou sua intervenção em outros processos.

Todavia, a jurisprudência brasileira vem decidindo que o amicus curiae, embora livre da prova de um interesse jurídico, deve demonstrar a "representatividade

44 O que se percebe do confronto da regra $n^{\circ} 92$ (já transcrita) e a regras $n^{\circ} 55$ e 57 da Suprema Corte canadense: "Requête en intervention. 55. Toute personne ayant un intérêt dans une demande d'autorisation d'appel, un appel ou un renvoi peut, par requête à un juge, demander l'autorisation d'intervenir. (...) 57. (I) L'affidavit à l'appui de la requête en intervention doit préciser l'identité de la personne ayant un intérêt dans la procédure et cet intérêt, y compris tout préjudice que subirait cette personne en cas de refus de l'autorisation d'intervenir", disponível em http://www.scc-csc.gc.ca/, acessado em 26.10.2003.

45 Veja-se, por exemplo, a Order 11 Rule 22 em relação à Admiralty intervention e a Order 17 Rule $I$ referente ao Third party procedure. A integra das regras está disponivel em http://www.hcourt.gov.au, acessado em 26.10.2003.

46 BAUR, Fritz e GRUNSKY, Wolfgang. Op.cit., pp. 211-212.

47 JAUERNIG, Othmar. Op.cit., pp. 346-347, em relação à assistência, afirma in verbis: "Die Entscheidung, die im Prozeß ergeht, hat keine materielle Rechtskraft gegen den Nebenintervenienten als solchen (sie kann es aus anderen Gründen haben, z.B., weil er Rechtsnachfolger ist). Sie entfaltet aber () eine ähnliche Wirkung, die sog. Interventionswirkung, im Verhältmis des Nebenintervenienten zur Hauptpartei, \$68. Er kann dieser gegenüber (z.B. in dem Regreßprozeß, den die unterlegene Partei gegen ihn führt) nicht behaupten, der Prozeß sei unrichtig entschieden: aamit ist alisgeschlossen, daß die in Vorprozeß unterlegene Hauptpartei jetzt aus Gründe wnterliegt, die mit der ersten Klagabweisung unvereinbar sind". Cf. KUMMER, Max. Op.cit., p.139; BAUR, Fritz e GRUNSKY, Wolfgang. Op.cit., p.104. 
adequada", ${ }^{48}$ o que poderia sinalizar como uma outra diferença entre esta modalidade de intervenção e aquelas previstas no CPC. Não obstante a autoridade dos que defendem este posicionamento, pensamos não se aplicar ao amicus curiae tal exigência. A representatividade adequada (adequacy of representation) é requisito utilizado nas class actions norte-americanas para que o tribunal possa aferir se a parte que está em juízo defendendo direito supraindividual tem capacidade técnica e empreenderá uma proteção efetiva aos interesses dos membros da coletividade, que poderá ser atingida pelos efeitos da decisão e pela formação da coisa julgada mesmo em relação aos ausentes do litígio, como é típico nas demandas coletivas. ${ }^{49}$ A representação adequada, prevista nas Federal Rules of Civil Procedure [Rule 23 (a)(4)],$^{50}$ liga-se diretamente à questão da vinculação da decisão àqueles que não tenham participado do processo (absent class members) e que, diante da substituição processual, possam ser prejudicados pela atuação deletéria da representative party. Assim, justifica-se o requisito diante do perigo da representação inadequada, que pode vincular, pela coisa julgada, aqueles que não participaram do processo, conforme entendimento pacífico em doutrina. ${ }^{51}$

Ora, não obstante a previsão no art $7^{\circ} \S 2^{\circ}$ da Lei $9.868 / 99$ de que deverá ser verificada a "representatividade" do amicus curiae para que seja deferida a intervenção, pensamos que aqui não existe obrigatoriedade desta exigência, já que não há substituição processual. Vale dizer: o amicus curiae não vai a juízo em nome próprio na defesa de direito alheio, não sendo legitimado extraordinário. Por outro lado, as partes que debatem em torno do direito material estão presentes no processo. Logo, não há risco de representação inadequada e desnecessário o exame da adequacy of representation. Acrescente-se que as demais disposições normativas referentes ao instituto no âmbito da CVM, do Cade, e da intervenção da União Federal e de terceiros desinteressados nos processos administrativos nada mencionam acerca da representatividade adequada, pelo que a base legal do instituto é outro argumento que favorece a tese aqui exposta, no sentido da desnecessidade do requisito, somente encontrado na Lei $9.868 / 99$. A presença ou ausência de representatividade adequada não é diferença entre a intervenção do amicus curiae e a disciplina clássica da intervenção de terceiros, já que tal requisito não existe para ambos os casos.

Outra disparidade na disciplina das modalidades de intervenção previstas no CPC para a intervenção do amicus curiae é que esta poderá ser espontânea ou

48 STF - Medida Cautelar na Adin. 2.130-SC Relator: Min. Celso de Mello, publicada no DJU em 02.02.2001: "Tendo presentes as razões ora expostas - e considerando o que dispõe o art. $7^{\circ}$, $\S 2^{\circ}$, da Lei $n^{\circ} 9.868 / 99$ - entendo que se acham preenchidos, na espécie, os requisitos legitimadores da pretendida admissão formal, da ora interessada, nesta causa: a relevância da matéria em exame, de um lado, e a representatividade adequada da entidade de classe postulante, de outro".

49 MENDES, Aluisio Gonçalves de Castro. Op.cit., p. 80.

50 Rule 23 (a)(4): "the representative parties will fairly and adequately protect the interests of the class".

51 Por todos, MENDES, Aluisio Gonçalves de Castro. Op.cit., pp.80-83; PINHO, Humberto Dalla Bernardina de. A natureza jurídica do direito individual homogêneo e sua tutela pelo Ministério Público como forma de acesso à justiça. Rio de Janeiro: Forense, 2002, p.155. 
determinada pelo magistrado. Com efeito, até a previsão normativa do amicus curiae, inexistia no ordenamento processual modalidade de intervenção de terceiros que pudesse ser ordenada pelo órgão julgador, já que, ainda quando a intervenção é forçada ou coata, é a parte que provoca a inserção do terceiro no processo, ${ }^{52}$ sendo maciço o entendimento de que o juiz somente pode determinar a vinda de terceiro ao processo quando se tratar de hipóteses de litisconsórcio. $\mathrm{Na}$ Itália, por exemplo, pode o magistrado determinar a intervenção de um terceiro (intervento per ordine del giudice) quando a "causa lhe for comum", cláusula indeterminada cuja interpretação tem sentido diverso do termo "interesse jurídico". ${ }^{53-54}$ A previsão normativa do amigo da corte no Brasil permite que o magistrado relator requisitar informações, ouvir depoimentos e designar peritos (arts. $9^{\circ} \S 1^{\circ}$ e $20 \S 1^{\circ}$ da Lei 9.868/99; art.31 e 32 da Lei 9.784/99). ${ }^{55}$

\section{O "amicus curiae": a intervenção pelo "interesse público"}

Quando analisamos os objetivos políticos do direito processual, identificamos, na esteira da melhor doutrina, o fomento da participação do indivíduo no conjunto

52 LIEBMAN, Enrico Tullio. Op.cit., pp.119-120.

53 Codice di Procedura Civile, Art.107.Intervento per ordine del giudice - Il giudice, quando ritiene opportuno che il processo si svolga in confronto di un terzo al quale la causa è comune. ne ordina l'intervento.

54 ZANZUCCHI, Marco Tullio. Op.cit., pp.336-337. Diz o autor que a expressão "causa comum" é compreendida de forma pacífica na doutrina e jurisprudência italianas como identidade entre a relação jurídica de direito material discutida por autor e réu e aquela pretendida pelo interveniente: "il rapporto sostanziale, intorno a cui pende la lite fra attore e convenuto, sai contune al terzo (nel qual caso il terzo avrebbe potuto o dovuto assumere posizione di litisconsorte necessario: art.102)". 55 Na Suprema Corte Norte-Americana, a admissão do amicus curiae depende, em regra, da atuação e do consentimento das partes. Somente será permitido que o tribunal determine a intervenção, quando o interveniente explicitar suas razões e seu "interesse", ainda que não "jurídico". Deve haver, portanto, provocação da corte pela parte. Diz a Rule 37.2: “2. (a) An amicus curiae brief submitted before the Court's consideration of a petition for a writ of certiorari, motion for leave to file a bill of complaint, jurisdictional statement, or petition for an extraordinary writ, may be filed if accompanied by the written consent of all parties, or if the Court grants leave to file under subparagraph 2(b) of this Rule. The brief shall be submitted within the time allowed for filing a brief in opposition or for filing a motion to dismiss or affirm. The amicus curiae brief shall specify whether consent was granted, and its cover shall identify the party supported.(b) When a party to the case has witheld consent, a motion for leave to file an amicus curiae brief before the Court's consideration of a petition for a writ of certiorari, motion for leave to file a bill of complaint. jurisdictional statement, or petition for an extraordinary writ may be presented to the Court. The motion. prepared as required by Rule 33.1 and as one document with the brief sought to be filed, shall be submitted within the time allowed for filing an amicus curiae brief, and shall indicate the party or parties who have witheld consent and state the nature of the movant's interest. Such a motion is not favored". A exigência da demonstração do interesse. todavia, é dispensada quando o ente que se manifesta como amicus curiae é o solicitor general, condado, cidade, estado-membro, território, agências governamentais que possuam previsão legal para a intervenção, em todos os casos quando a petição for encaminhada pelo seu procurador-geral (Rule 37.4). 
de decisões políticas do Estado como um daqueles escopos. Exemplificamos alguns institutos existentes no ordenamento brasileiro que cumprem este papel, notadamente a ação popular e o amicus curiae, estendido recentemente pela Lei 9.868/99 (art.7 ${ }^{\circ}$ $\S 2^{\circ}$ ) aos processos de controle de constitucionalidade.

Pensamos que o amigo da corte deve representar um gatilho de participação popular que não fique restrito aos processos de controle abstrato da constitucionalidade ou tampouco aos incidentes de reserva de plenário nos tribunais, mas a todo caso em que houver interesse público envolvido, como se tentará demonstrar a seguir, prestando o instituto, ainda, para ampliar a manifestação processual a indivíduos, órgãos e entidades até mesmo estrangeiros ou transnacionais, em casos onde em discussão elementos e dilemas universais.

\subsection{Fundamentos da aplicação do instituto em casos de interesse público: democracia participativa e colaboração para a justa decisão}

\subsubsection{O interesse em participar: aporte democrático. Análise do interesse público nas intervenções como "amicus curiae" da CVM, do Cade, da União Federal e de entidades no processo administrativo.}

Vimos anteriormente que o amicus curiae foi adotado pela legislação nacional no âmbito da jurisdição constitucional em atenção às modernas teorias constitucionalistas que abordam a atividade de interpretação da constituição como um processo amplo e aberto, cabendo não só aos juristas e magistrados, mas a toda a sociedade, intérprete "em sentido amplo da constituição" ${ }^{56} \mathrm{O}$ instituto foi previsto não só para o controle de constitucionalidade em abstrato, como também no controle difuso concreto, exercitado in casu. Essa constatação tem extrema relevância. Com efeito, o controle abstrato da constitucionalidade desenvolve-se em processo que ganha a qualificação de "objetivo", ou seja, desvinculado de interesses e direitos subjetivos das partes envolvidas, voltado tão-somente à tutela da pureza do ordenamento jurídico.

Por outro lado, o controle difuso incidental pode ser exercido em qualquer litígio intersubjetivo, em que o magistrado deve buscar proteger direitos das partes. Ora, aqui não se trata de tutelar o próprio ordenamento jurídico, mas responder à demanda inicial, julgando o pedido e atribuindo a uma das partes o bem da vida sobre o qual controvertem. A ratio da possibilidade do amicus curiae no controle difuso concreto da constitucionalidade reside na sua importância política, ou seja, no interesse público de participar da jurisdição constitucional.

Trata-se de concepção no sentido de que, quando em jogo a tarefa de afastar a aplicação de normas constitucionais, impende ampliar-se o contraditório para outros terrenos sociais, ainda que além dos limites do litígio inter partes. 
E, em atenção ao mesmo fundamento, deve haver aplicação das mesmas normas (ubi eadem ratio ibi eadem legis dispositio). Com efeito, foi visto que o amigo da corte já tinha previsão normativa antes de sua inclusão no âmbito da jurisdição constitucional. Logo, não só nesta seara deverá incidir o instituto do amicus curiae, mas em qualquer outro processo em que presente o interesse público na participação processual, já que se trata de instrumento garantidor da participação democrática. ${ }^{57}$

As normas que permitem a intervenção da CVM, do Cade e da União Federal e ainda no processo administrativo federal, fazem-no desconsiderando o interesse jurídico, o que também aponta para o reconhecimento da condição de amicus curiae nestas modalidades de intervenção.

Sem embargo, o fato de ser discutida em juízo matéria de atribuição administrativa da CVM (art.31, caput, Lei 6.385/76, com relação dada pela Lei 6.616/78: "matéria incluída na competência da CVM") não caracteriza interesse jurídico, pois a CVM não possui relação jurídica ligada àquela deduzida no processo. Sem embargo, a intervenção da CVM como amicus curiae dar-se-á toda vez que, mesmo em processos de caráter individual, houver discussão judicial de matérias que, no âmbito administrativo, sujeitam-se à fiscalização da entidade. Patente o interesse público no controle de atividades comerciais referentes ao direito societário, o que autoriza a intervenção. ${ }^{58}$

Por outro lado, como afirma o art. $5^{\circ}$, parágrafo único, da Lei 9.469/97, a intervenção da União Federal como amicus curiae poderá ocorrer independentemente da demonstração de interesse jurídico, quando a decisão puder ter efeitos de natureza econômica, ainda que reflexos, mediatos. ${ }^{59}$ Aqui a própria lei é clara e expressa em denotar a intervenção do amigo da corte, separando-a frontalmente da assistência juridicamente interessada do CPC.

Por outro lado, o art. 89 da Lei 8.884/94 autoriza a intervenção do Cade "nos processos em que se discuta a aplicação desta lei", que ocorrerá, como preceitua o art. $1^{\circ}$, para a prevenção e a repressão às infrações contra a ordem econômica, preservação da livre concorrência, da função social da propriedade, e repressão ao abuso do poder econômico. As hipóteses de intervenção denotam claramente a atividade fiscalizatória do Cade, semelhante à previsão existente para a CVM.

Porém, cabe notar que a lei diz que o Cade intervém "na qualidade de assistente". Não obstante o texto da lei, certamente não se trata de assistência, pois não há qualquer interesse jurídico do Cade nestes litígios vez que, assim como visto em relação à $\mathrm{CVM}$, inexiste relação jurídica material entre o Conselho e as partes

57 MACIEL, Adhemar Ferreira. "Amicus curiae: um instituto democrático", Op.cit., pp.281-282, onde se lê que o amicus curiae é "instituto de caráter democrático, uma vez que permite, tirando um ou outro caso de nítido interesse particular, que terceiros penetrem no mundo fechado e subjetivo do processo para discutir objetivamente teses jurídicas que vão afetar toda a sociedade".

58 CARNEIRO, Athos Gusmão. "Mandado de Segurança-Assistência e amicus curiae", Op.cit., p. 41.

59 CARNEIRO, Athos Gusmão. "Da intervenção da União Federal como amicus curiae.(...)". Op.cit., p. 187. 
envolvidas. Ainda uma vez, a intervenção aqui decorre do interesse público presente naquelas hipóteses previstas no art. $1^{\circ}$ da Lei $8.884 / 94$. De fato, o interesse público nestes casos é admitido pela própria lei $8.884 / 94$, que afirma, em seu art. $1^{\circ}$, o parágrafo único que "a coletividade é a titular dos bens jurídicos protegidos por esta lei”. Na aplicação das penas previstas, afirma ainda o legislador que influenciará a decisão os efeitos que a infração possa ter causado à economia, aos consumidores e terceiros. ${ }^{60} \mathrm{Em}$ seguida (art.24), afirma a normativa federal que o Cade pode, administrativamente, impor algumas medidas reparatórias quando houver "interesse público geral". Dentre essas medidas está a publicação em jornais, às expensas do infrator, da decisão condenatória em processo administrativo, ${ }^{61}$ visando a conferir grande publicidade às infrações contra a ordem econômica e permitir a manifestação de outros setores sociais interessados.

No campo da intervenção do amicus em processos administrativos, prevista de forma genérica pela Lei 9.784/99, o art.31 afirma que será cabível a manifestação quando a matéria debatida no processo "envolver assunto de interesse geral". Abrese oportunidade para o órgão administrativo realizar consultas e até audiências públicas, além de admitir a manifestação escrita de terceiros que não se confundem com os interessados diretamente no resultado do processo. ${ }^{62} \mathrm{O}$ próprio $\S 2^{\circ}$ do art. 31 é peremptório em afirmar que a manifestação do amigo da corte na consulta pública não enquadra este terceiro sui generis no conceito de "interessado" previsto nos arts. $9^{\circ}$ e 58 da Lei 9.784/99, que se aproxima da idéia de interesse jurídico, já que está intimamente ligado à existência de relação jurídica do interessado que poderá ser afetada pelo processo administrativo. O amicus curiae não possui este interesse e sua intervenção não o torna interessado. ${ }^{63}$

Com efeito, desde há muito já se rompeu com os dogmas civilistas que afirmavam que o direito processual seria disciplina afeta ao direito privado, e que as decisões proferidas no curso do processo somente abrangeriam interesses individuais. ${ }^{64}$ As ações civis coletivas são prova inegável da superação deste paradigma,

60 Art. 27. Na aplicação das penas estabelecidas nesta lei serão levados em consideração: (...)V — o grau de lesão, ou perigo de lesão, à livre concorrência, à economia nacional, aos consumidores, ou a terceiros; VI — os efeitos econômicos negativos produzidos no mercado;

61 “Art. 24. Sem prejuízo das penas cominadas no artigo anterior, quando assim o exigir a gravidade dos fatos ou o interesse público geral, poderāo ser impostas as seguintes penas, isolada ou cumulativamente: I - a publicação, em meia página e às expensas do infrator, em jornal indicado na decisão, de extrato da decisão condenatória, por dois dias seguidos, de uma a três semanas consecutivas;"

62 "Art. 31. Quando a matéria do processo envolver assunto de interesse geral, o órgão competente poderá, mediante despacho motivado, abrir período de consulta pública para manifestação de terceiros, antes da decisão do pedido, se não houver prejuízo para a parte interessada. $\S 1^{\mathfrak{Q}} \mathrm{A}$ abertura da consulta pública será objeto de divulgaçāo pelos meios oficiais, a fim de que pessoas físicas ou jurídicas possam examinar os autos, fixando-se prazo para oferecimento de alegações escritas".

63 “Art.31 (...) $\S 2^{\circ} \mathrm{O}$ comparecimento à consulta pública não confere, por si, a condição de interessado do processo, mas confere o direito de obter da Administração resposta fundamentada, que poderá ser comum a todas as alegaçōes substancialmente iguais." 
no que tange à proteção de interesses transindividuais. Em sua disciplina, consagra - legislador a legitimidade extraordinária (através do mecanismo da substituição processual) de associações civis, órgãos públicos e do Ministério Público. São previstos ainda efeitos da coisa julgada erga omnes ou ultra partes, que escapam à sistemática tradicional das demandas individuais. $\mathrm{E}$ a reboque deste movimento de publicização deve ser interpretado o amicus curiae como um instrumento da democracia participativa, desvinculado da figura das partes.

$O$ interesse público na manifestação em processos judiciais justifica-se em vista dos objetivos da jurisdição e também do aspecto de ordem pública presente nos princípios do contraditório e da motivação das decisões judiciais, como abordaremos a seguir.

\subsubsection{A colaboração como imperativo jurídico do contraditório}

O processo desenvolve-se em um ambiente dialético: às manifestações do autor sobrepõem-se as do réu. Desse embate, extrai o magistrado a solução ao caso concreto levado à apreciação do Judiciário, na medida em que se confere às partes possibilidade de sustentar e argumentar buscando a vitória. Não se coadunaria com um Estado Democrático de Direito a prolação de uma decisão expressão de poder estatal sem a intervenção participativa dos indivíduos que sofrerão seus efeitos. Este é o fundamento do princípio do contraditório, de permitir ampla manifestação e argumentação dos sujeitos processuais. O contraditório é o elemento que fornece ao processo tal dialeticidade, diferenciando-o do mero procedimento e permitindo um "diálogo judicial para a formação do juízo" do magistrado (Rechtsgespräch). ${ }^{65}$

Nota-se, porém, que a participação das partes também presta relevante contributo para o labor jurisdicional. Sem embargo, a participação não só tem o escopo de garantir que cada um possa influenciar na decisão mas também tem uma finalidade de colaboração com o exercício da jurisdição. Dinamarco afirma que "o juiz exerce a jurisdição com a colaboração das partes" e essa dialética processual acaba revertendo em prol da "boa qualidade da prestação jurisdicional" 66

Com efeito, a lide terá a solução mais justa e o direito objetivo será tão mais resguardado quanto maior for a participação dos atores do processo. O contraditório assume função ainda mais nobilitante: a participação deixa de ser apenas indicativo de justa possibilidade de manifestação para configurar colaboração para uma solução

64 BARBOSA MOREIRA, José Carlos. "Processo civil e processo penal: mão e contramão?", in Temas de Direito Processual - 7 Série. São Paulo: Saraiva, 2001, p. 204, in verbis: "o desfecho de um pleito civil pode afetar, e com frequiência afeta, na vida em sociedade, zonas mais extensas do que aquela em que trafegam os interesses pessoais dos litigantes".

65 TARZIA, Giuseppe. "O contraditório no processo executivo" in Revista de Processo, n²8, outubro-dezembro de 1982, p.56; OLIVEIRA, Carlos Alberto Álvaro. “A garantia do contraditório" in Revista Forense, vol.346, abril-junho, 1999, p.12.

66 DINAMARCO, Cândido. Fundamentos do Processo Civil Moderno. São Paulo: Revista dos Tribunais, 2 Ed., 1987, p. 90. 
justa. O processo é "uma atividade de sujeitos em cooperação" 67 e a "co-participação" das partes na formação do decisum é uma "exigência" decorrente do princípio constitucional do contraditório. ${ }^{68}$

De fato, o princípio do contraditório é invocado, muito freqüentemente, como a maior arma dos litigantes para assegurar sua manifestação no processo e, não ousaríamos diminuir tamanha importância desta garantia. Certamente que, até quando exercitado, vale dizer, até o momento em que a parte pronuncia-se no processo, o contraditório representa o direito de ter ciência dos atos processuais e ver suas considerações apreciadas pelo órgão judicial. No entanto, uma vez atuando em juízo, a garantia ultrapassa tais fronteiras e cede espaço para um objetivo maior, que é a participação colaborativa nas decisões estatais, ${ }^{69}$ fato que justifica inclusive a repressão às condutas de litigância de má fé e aos atos atentatórios à dignidade de justiça: se participar é garantido, a atuação deve ser ética, consentânea com os objetivos estatais da jurisdição. ${ }^{70}$

Ora, diante desta função colaborativa do princípio do contraditório, outra não poderia ser a compreensão do amicus curiae senão aquela aqui defendida, no sentido

67 DINAMARCO. Cândido Rangel. Litisconsórcio. Op.cit., pp.18-21. Ressalte-se que outra parte da doutrina não explicita tal afirmação como decorrência lógica do princípio do contraditório. Confira-se, acerca das consequiências do contraditório, por todos, THEODORO JR., Humberto. Sentença. Rio de Janeiro: Aide, 1991, p.11

68 BARACHO, José Alfredo de Oliveira. " Constituição e Processo. O modelo constitucional e a teoria geral do processo constitucional. Natureza e categoria dos princípios processuais inseridos na constituiçâo" in Revista Forense, vol.353, janeiro-fevereiro, 2001, p.146.

69 CINTRA, Antonio Carlos Araújo et alii. Op.cit., p. 56, ipsis litteris: "cada um dos contendores age no processo tendo em vista o próprio interesse, mas a ação combinada dos dois serve à justiça (...)". Note-se que em doutrina ainda se controverte acerca da matéria. Há autores que negam a obrigatoriedade da existência de um diálogo judicial (Rechtsgespräch) entre os sujeitos do processo, admitindo somente que o contraditório importa em direito das partes de ver seus argumentos levados em consideração para a decisão. Cf. BAUR, Fritz e GRUNSKY, Wolfgang. Op.cit., p.28: "Zu einem Rechtsgespräch ist der Richter aber nicht verpflichtet". Na página 44, assevera que "Das Gericht ist verpflichtet, die Ausführungen der Prozeßbeteiligten zur Kenntnis zu nehmen und in Envägung $z u$ ziehen". No sentido do texto, TROCKER, Nicolò. "Il nuovo articolo 111 della costituizione $e$ il 'giusto processo' in materia civile: profili generali", in Rivista trimestrale di Diritto e Procedura Civile, Anno LV, n.2, junho, 2001, p. 394, afirmando que as manifestações do contraditório "oltre ad operare nei confronti delle parti, si convertono pure in un dovere-onere del giudice, cui spetta non soltanto di far osservare, ma di osservare egli stesso il fondamentale principio, si da provocare anche d'ufficio il preventivo dibattito delle parti su ogni questione di fatto o di diritto, la cui risoluzione sia determinante nella decisione della controversia". O novo Código de Processo Civil francês, em seu art.16, estabelece um dever do magistrado de fazer observar e observar ele próprio o contraditório, permitindo um "debate" entre as partes e órgão jurisdicional em torno dos argumentos constantes dos autos ("Art.16. Le juge doit, en toutes circonstances, faire observer et observer lui-même le principe de la contradiction. Il ne peut retenir, dans sa décision, les moyens, les explications et les documents invoqués ou produits par les parties que si celles-ci ont été à même d'en débattre contradictoirement. Il ne peut fonder sa décision sur les moyens de droit qu'il a relevés d'office sans avoir au préalable invité les parties à présenter leurs observations).

70 OLIVEIRA, Carlos Alberto Álvaro. "A garantia do contraditório", Op.cit., p.16. 
de estender o espectro de aplicação do instituto. Com efeito, se a jurisdição se exerce em colaboração com os sujeitos do processo, nada mais acertado que admitir ampla participação da sociedade, permitindo que manifestações diversas sejam trazidas ao processo pelo amigo da corte. Esses elementos prestarão para a dialética processual, adicionando outros pontos de vista àqueles das partes. ${ }^{71}$ Cappelletti afirma, com propriedade, que "el princípio contradictorio proporciona el carácter participativo a la justicia". ${ }^{72}$

Cabe destacar que esta dimensão participativa do contraditório fundamenta um peculiar requisito que alguns ordenamentos estabelecem para a intervenção do amicus curiae. Se não existe necessidade de demonstração de um interesse jurídico, $o$ conteúdo da manifestação do amigo da corte deve ser apto a prestar uma relevante contribuição para a decisão.

Assim, a Rule 37 do Regimento Interno da Suprema Corte norte-americana não menciona o interesse como requisito para a intervenção. Ao contrário, dispõe que poderá ocorrer a manifestação quando o amigo da corte trouxer "matéria relevante" (relevant matter), ainda não aduzida pelas partes (not already brought to its attention by the parties), afirmando ainda que tal contribuição será de grande ajuda para a corte (may be of considerable help to the Court), o que denota a ligação íntima do instituto com a participação através do contraditório. ${ }^{73}$ No caso Romer $v$. Evans já mencionado, onde a intervenção do amicus curiae foi decisiva para o julgamento, a própria petição do amigo da corte afirmava que as informações trazidas contribuiriam para "ajudar" a corte em suas considerações acerca do caso. ${ }^{74}$

Impende salientar que não se propõe aqui a "intrusão" indevida de terceiros alheios ao litígio de caráter estritamente individual. O permissivo à oitiva do amicus curiae é a presença de interesse público no processo, o que impõe a ampliação do contraditório em virtude: a) do mandamento da participação como objetivo político do processo e b) do postulado de depuração da prestação jurisdicional, pelo aspecto colaborativo do contraditório. O próprio art. $7^{\circ} \S 2^{\circ}$ da Lei $9.868 / 99$ afirma que a intervenção do amicus curiae poderá ser autorizada tomando-se em consideração a "relevância da matéria" discutida. Ora, quando há interesse público, pensamos tratar-se de matéria relevante. A Lei $9.784 / 99$ também estabelece que a intervenção

71 PEREIRA, Milton Luiz. “Amicus curiae - Intervenção de terceiros", Op.cit., p. 43.

72 CAPPELLETTI, Mauro. "El Tribunal Constitucional en el sistema público italiano", apud ALONSO GARCIA, Enrique. La Interpretacion de la Constitucion. Madrid: Centro de Estudios Constitucionales, 1984, pp. 87-88

73 Rule 37. Brief for an Amicus Curiae. 1. An amicus curiae brief that brings to the attention of the Court relevant matter not already brought to its attention by the parties may be of considerable help to the Court. An amicus curiae brief that does not serve this purpose burdens the Court, and its filing is not favored.

74 "Amici believe that this Court's consideration of this case will be aided by presentation of the literature demonstrating the baselessness of, and harms caused by, such discrimination()". Leia-se a íntegra da petição em http://www.apa.org/pi/romer.html, acessado em 26.10.2003, disponível também em http://www.psyclaw.org/romerbrief.html, acessado em 26.10.2003. 
poderá ser autorizada em audiência pública quando a autoridade administrativa reputar haver "questão relevante" em debate. ${ }^{75}$

Por outro lado, cabe analisar a repercussão do contraditório amplo no ato decisório, especialmente sob o prisma da motivação das decisões, espaço onde o órgão julgador expõe as razões que contribuíram para a formação de seu convencimento.

A fundamentação das decisões não pode mais ser compreendida como simples conclusão, à luz do silogismo jurídico, segundo o qual a norma seria a premissa maior e o fato a premissa menor. Afigura-se ainda mais patente tal assertiva quando se trata de interpretação e aplicação de normas que contêm, em número progressiva e constantemente maior, princípios jurídicos e conceitos indeterminados, em face da densidade axiológica de seus preceitos e a abstração de suas cláusulas. Certamente que a fundamentação das decisões envolve trabalho intelectual de conteúdo crítico e lógico e compreende o conjunto de reflexões de fato e de direito do qual o juiz extrai o julgamento. Entretanto, não se pode reduzir o labor jurisdicional a parâmetros cartesianos em virtude da multiplicidade de variáveis que envolvem a atividade decisória. Não podem ser as decisões lastreadas em raciocínio puramente formal, mormente no que tange a questões de interesse público. ${ }^{76}$

A atividade jurisdicional deve, dessarte, interagir com a realidade social, já que o sistema jurídico, desde a constituição até a normativa infra-constitucional, é uma ordem aberta. ${ }^{77} \mathrm{E}$, não apenas em sede de processos constitucionais, mas toda vez que estiver em jogo um relevante interesse público, a decisão concerne a toda a coletividade, na medida que os destinatários da prestação jurisdicional "não são apenas as partes e os órgãos jurisdicionais de impugnação, mas a opinião pública". ${ }^{78}$ Nesses casos, a atividade jurisdicional afeta toda a sociedade e ademais, através do processo, o Estado realiza objetivos que são próprios e que suplantam os interesses das partes.

Por um lado, é patente que a fundamentação das decisões judiciais atende a um interesse das partes, as quais, através da compreensão das razões de decidir do juiz, podem-se conformar com o erro de suas condutas e se educar (relevância da motivação no objetivo social de pedagogia da comunidade), ou se irresignar e preparar adequadamente seus recursos. Contudo, não se pode afastar o inegável interesse público na fundamentação das decisões judiciais. Este interesse revela-se no controle da atividade jurisdicional (pelas instâncias superiores de revisão da matéria decidida

75 "Art. 32. Antes da tomada de decisão, a juízo da autoridade, diante da relevância da questão, poderá ser realizada audiência pública para debates sobre a matéria do processo".

76 CALAMANDREI, Piero. "Processo e Democrazia" in Opere Giuridiche. Napoli: Morano Editore, vol.1, p. 646, onde se lê:"chi si immagina la sentenza come un sillogismo, non vede la sentenza viva; vede la sua spoglia, il suo scheletro, la sua mummia".

77 CANOTILHO, José Joaquim Gomes. Direito Constitucional e Teoria da Constituição, Coimbra: Almedina, 1998, pp.1.033.

78 CRUZ e TUCCI, José Rogério. A motivaçāo da Sentença no Processo Civil. São Paulo: Saraiva, 1987, pp.21-24 
e também pela própria sociedade, através da censura pública à jurisprudência) e na garantia de participação política através do processo.

Releva frisar que o Codice de Procedura Civile italiano, em seu art.132, caput, atesta que a sentença é pronunciada em nome do povo italiano, ${ }^{79} \mathrm{em}$ notada postura de enunciar, explicitamente, o interesse público nas decisões judiciais. ${ }^{80}$ No mesmo sentido, o art.101 da constituição italiana diz que a justiça é prestada em nome do povo. Também o art. $117 \mathrm{n}^{\circ} 1$ da constituição espanhola de 1978 prega que "la justicia emana del pueblo." A constituição portuguesa, por sua vez, dispõe no art. 205 que "os tribunais são órgãos de soberania com competência para administrar a justiça em nome do povo".

A decisão deve expressar a melhor resolução do litígio, acolhendo ou refutando os argumentos constantes dos autos e as manifestações dos sujeitos processuais. $\mathrm{O}$ ato decisório tem de estampar de forma cristalina a síntese das contribuições colhidas pelo exercício do contraditório, ainda que seja para afastar os argumentos e elementos irrelevantes ou equivocados para a solução da lide. Neste contexto, a fundamentação das decisões comprova a observância dos objetivos políticos da jurisdição: concilia o culto à liberdade, pelo exercício da garantia do contraditório, com a expressão do aspecto colaborativo da participação, ao tomar em consideração a manifestação dos sujeitos do processo, inclusive do amicus curiae, quando houver interesse público.

\subsection{Conceito de interesse público}

A palavra interesse geralmente é acompanhada de adjetivos que nem sempre permitem especificá-lo (interesses sociais, privados, públicos, de Estado etc.).

Por "interesse público" entendemos aquele presente não só nos interesses transindividuais (difusos ou coletivos), que decerto se confundem por vezes com este conceito e nele se compreendem ${ }^{81}$ mas também os interesses individuais homogêneos, que embora titularizados individualmente, atingem significativas parcelas da população, o que justifica e autoriza a admissão do amicus curiae nestes casos.

Mas dentro de quais limites podemos compreender o significado do interesse público? Com efeito, o art. 82, III do CPC, ao definir hipóteses de atuação do Ministério Público, menciona que caberá sua intervenção, na condição de custos legis, em qualquer causa em que haja "interesse público evidenciado pela natureza da lide ou qualidade da parte".

79 Ipsis Litteris: “Art.132. La sentenza è pronunciata in nome del popolo italiano e reca l'intestazione: Repubblica Italiana".

80 Veja-se, também, o art.111 da Constituição Italiana de 1948, art.120 n³ da Constituição Espanhola de 1978 e o art.210 da Constituição Portuguesa de 1976 sobre a fundamentação das decisões. Confira-se BATTAGLINI, Mario et alli. Codice de Procedura Civile e Norme Complementari con il commento della giurisprudenza della cassazione. $10^{2}$ Ed. Milano: A. Giuffrè Editore, 1996, pp. 644-648

81 Seguimos aqui a linha descrita por MENDES, Aluisio Gonçalves de Castro. Op.cit., p. 203-204. 
Pensamos não ser este dispositivo um parâmetro seguro na conceituação do interesse público em razão de uma interpretação sistemática deste inciso com o restante do art. 82, onde há a enumeração de outros casos em que o MP deverá atuar, porém diante de interesses que não representam impacto social de massa. Em casos de destituição de pátrio poder, interesses de incapazes, casamento etc., ainda que relevantes a ponto de merecer a atuação do Ministério Público, pensamos não poderem ser incluídos na conceituação de interesse público para fins de admissibilidade da participação do amicus curiae. ${ }^{82}$

Porém, a própria Constituição da República de 1988, em alguns pontos, fornece embasamento normativo para nortear a atuação dos magistrados no que tange à delimitação do que significa "interesse público". Em seu art.197, diz o legislador constituinte que se consideram os serviços e ações de saúde como de "relevância pública", cabendo sua execução e fiscalização não só ao Poder Público, mas também à comunidade (veja-se também o art.198, III) ${ }^{83} \mathrm{~A}$ gestão da ordem econômica será realizada com "justiça social" e visando à proteção do consumidor, devendo ser reprimido o abuso de poder econômico (arts. 170 e $173 \S 4^{\circ}$, regulamentado pela Lei $8.884 / 94)$. O meio ambiente é "bem de uso comum do povo" e sua manutenção no estado "ecologicamente equilibrado" é direito de todos, sendo também sua defesa um dever atribuído a toda a coletividade (art. 225, caput). As ações governamentais na área de assistência social serão empreendidas com a "participação da população" não apenas no que se refere ao controle e fiscalização mas também em relação à "formulação de políticas" (art. 204, II), o que ressalta a idéia de contribuição, colaboração da sociedade, pluralista e heterogênea, em seus diversos setores, para a vida política da república. Aliás, na gestão da res publica, impõe-se publicidade e participação.

Outras normas contribuem para delinear os contornos essenciais deste conceito jurídico indeterminado. As hipóteses de cabimento da ação popular também representam guias neste mister: temas como a preservação da moralidade administrativa, do patrimônio público, histórico, artístico, cultural (art. $5^{\circ} \mathrm{LXXIII,CR/88),} \mathrm{proteção}$ do patrimônio genético (art. 225, II), e outros, certamente denotam presença de interesse público. Temas como as condições de encarceramento prisional também apontam neste sentido. A segurança pública é definida pela Lei Maior (art.144) como "direito e responsabilidade de todos". A Lei de Execuções Penais (LEP), em seu art. $4^{\circ}$, afirma que na aplicação das penas o Estado deve "recorrer à cooperação da comunidade", em notável iniciativa de garantir a participação, no que o instituto do amicus curiae é essencial e pode ser aplicado nos procedimentos especiais em execuções penais, previstos no art. 194 e seguintes da LEP.

82 Alguns setores doutrinários afirmam que a figura do Vertreter des öffentlichen Interesses, prevista originariamente para o processo administrativo alemão e posteriormente analisada no texto, teria sido estendida pelo legislador tedesco ao processo jurisdicional nas causas de direito de família sendo, nestes casos, de incumbência do Ministério Público (Staatsanwalt), e se assmelharia ao amicus. Nesta perspectiva, que não é nosso entender, poder-se-ia imaginar o art. 82 do CPC um parámetro seguro para a identificação do que é interesse público apto a autorizar a intervenção. §3 PEREIRA, Milton Luiz. “Amicus curiae - Intervenção de terceiros", Op.cit., pp. 41-42. 
A participação através do contraditório é a base normativa que justifica a intervenção do amicus. ${ }^{84} \mathrm{O}$ debate público que se desenvolve perante o Judiciário na atualidade transborda os limites da individualidade e do patrimonialismo. ${ }^{85}$ Questões sociais como sistema de ensino e hospitalar, controle da aplicação e gestão de verbas públicas, dentre outras, são prova irrefutável de que a concepção privatista do processo, já abandonada em certas particularidades da ciência processual, deve também imperar no campo da intervenção de terceiros, consagrando-se a extensão do campo de aplicação do instituto do amicus curiae, desvinculando a admissibilidade de sua intervenção à demonstração de um interesse jurídico, quando sua manifestação decorre dos postulados da democracia deliberativa e da dimensão participativa do contraditório.

\section{6. $O$ "amicus curiae" e o "Vertreter des öffentlichen Interesses". $O$ representante do interesse público no processo administrativo na Alemanha e no Brasil}

A intervenção ampla do amicus curiae com base no interesse público ganha força na doutrina e jurisprudência brasileiras, defendida dentre outros pelo Min. Milton Luiz Pereira, ${ }^{86}$ e já é consagrada em outros países. Também Athos Gusmão Carneiro, que se dedica ao tema, sustenta a possibilidade de intervenção com base no interesse público. ${ }^{87}$

84 CARNEIRO, Athos Gusmão. "Mandado de Segurança-Assistência e amicus curiae", Op.cit., p. 41 , onde se lê: "Embora forte corrente jurisprudencial ainda considere incabível qualquer modalidade de intervenção de terceiro na ação de mandado de segurança, as mais ponderáveis razões jurídicas e pragmáticas indicam, neste momento em que o Direito busca a eficiência no processo, capacitando-o à justa resolução da lide com base em um contraditório amplo, a necessidade de abandonar a orientação restritiva e, assim, permitir que o terceiro interessado, máxime um sindicato, possa intervir no processo do mandamus quer como assistente litisconsorcial, quer em assistência simples, quer, quiçá, se a demanda versar matéria de interesse público, na qualidade de amicus curiae".

85 BARACHO, José Alfredo de Oliveira. Op.cit., p.194.

86 Neste sentido, PEREIRA, Milton Luiz. "Amicus curiae - Intervençāo de terceiros", Op.cit., pp. 40-41, in verbis: "No entanto, a trato de instituto de maior abrangência e com homenagens à efetividade e à economia processual, a intervenção do amicus curiae ganha permissão, sobretudo quando se projetar a conveniência de o direito disputado ter alargadas suas fronteiras, máxime do interesse público, facultando a composição judicial com o conhecimento de todas as suas implicações ou repercussões (...). Essas realidades imantam a necessidade de ampliado acesso ao Judiciário, por si, abrindo o pórtico ao terceiro (cidadão ou ente público), também interessado na solução da controvérsia. No entanto, em tais casos, o litígio prende-se à solução apropriada, permitindo fluir o 'interesse subjetivo público', legitimador da participação processual (...). Essa participação ganhará mais relevo quando, nos litígios entre pessoas diversas (privadas ou públicas), o thema decidendum da ação, insista-se, tenha típicas razões de interesse público, ou seja, quando transcenda a motivação dos litigantes, algemando-se à sociedade como um todo, ou ao próprio Estado."

87 CARNEIRO, Athos Gusmão. "Mandado de Segurança - Assistência e amicus curiae", Op.cit., p. 41 , onde defende a intervenção dos sindicatos como amicus curiae, já que a Constituição da 
$\mathrm{Na}$ Alemanha, a lei que disciplina o processo administrativo perante os tribunais (Verwaltungsgerichtsordnung) prevê nos seus $\$ 35$ a 37, uma modalidade de intervenção de terceiros denominada "representante do interesse público" (Vertreter des öfentlichen Interesses).

$\mathrm{O} \S 35$ dispõe que poderá o procurador federal (Oberbundesanwalt) intervir em qualquer processo administrativo perante o Tribunal Administrativo Federal para a observância de interesses públicos ("zur Wahrung des öffentlichen Interesses"). ${ }^{88}$

O $\S 36$ contém previsão mais genérica do permissivo de um terceiro interveniente ("representante do interesse público") no processo administrativo, que aqui não se limita apenas ao Tribunal Federal mas se estende também nos tribunais administrativos dos Ländern (Estados-membros), quando houver lei estadual autorizando. ${ }^{89}$

Tanto o procurador federal $(\S 35)$ como o representante do interesse público ( $\S$ 36) atuam com o fito de esclarecer ao tribunal qual o significado que o litígio possui para a coletividade. Devem demonstrar os efeitos e conseqüências que o julgamento pode ter além dos limites inter partes,,$^{90}$ e têm garantida a possibilidade de expressar seu ponto de vista manifestando-se no processo.

Ambas as figuras possuem atuações ligadas ao interesse público e muito se aproximam da configuração do amigo da corte do common law. O interesse público

República de 1988 afirma que exercem os sindicatos função de relevante interesse público. Cf. nota n. 84 supra. Na Alemanha, o $\$ 11$ da Lei do Tribunal do Trabalho (Arbeitsgerichtsgesetz) prevê uma possibilidade de representação das partes pelos sindicatos, o que, ainda que diferente da intervenção do amicus, aponta no mesmo sentido do reconhecimento da relevante função pública destas entidades. Diz o texto legal: " $\$ 11$.(1) IDie Parteien können vor den Arbeitsgerichten den Rechtsstreit selbst führen oder sich vertreten lassen. 2Eine Vertretung durch Vertreter von Gewerkschaften oder von Vereinigungen von Arbeitgebern oder von Zusammenschlüssen solcher Verbände ist zulässig, wenn diese Personen kraft Satzung oder Vollmacht zur Vertretung befugt sind und der Zusammenschluß, der Verband oder deren Mitglieder Partei sind. 3Das gleiche gilt für die Prozeßvertretung durch Vertreter von selbständigen Vereinigungen von Arbeitnehmern mit sozial- oder berufspolitischer Zwecksetzung.(...)"

88 " $\$ 35$ [Oberbundesanwalt bei dem Bundesverwaltungsgericht] (l) Bei dem Bundesverwaltungsgericht wird ein Oberbundesanwalt bestellt. Dieser kann sich zur Wahrung des öffentlichen Interesses an jedem Verfahren vor dem Bundesverwaltungsgericht beteiligen; dies gilt nicht für Verfahren vor den Disziplinarsenaten und Wehrdienstsenaten. Er ist an die Weisungen der Bundesregierung gebunden. (2) Das Bundesverwaltungsgericht gibt dem Oberbundesanwalt Gelegenheit zur Äußerung".

89 "§ 36 [Vertreter des öffentl. Interesses] (1)Bei dem Oberverwaltungsgericht und bei dem Verwaltungsgericht kann nach Maßgabe einer Rechtsverordnung der Landesregierung ein Vertreter des öffentlichen Interesses bestimmt werden. (2)Dabei kann ihm allgemein oder für bestimmte Fälle die Vertretung des Landes oder von Landesbehörden übertragen werden. (2) § 35 Abs. 2 gilt entsprechend".

90 HIRTE, Heribert. Op.cit., p.47, in verbis: "Die Hauptaufgabe des Vertreters des öffentlichen Interesses liegt (...) darin zu prüfen, welche Bedeutung ein Verfahren für die Gesamtheit hat. Er darf und muß daher prüfen, welche - auch tatsächlichen - Folgen ein Urteil für andere als die unmittelbar am Prozeß beteiligten Parteien hat. Zwar soll er bei seiner Tätigkeit daran mitwirken, 'daß das Recht sich durchsetzt', und dafür sorgen, daß das 'öffentliche Interesse' gewahrt wird". 
que autoriza sua intervenção é traduzido em outros países como "interesse geral", cláusula bem ampla, como sustentado no texto. ${ }^{91}$ No Brasil, atuação semelhante é prevista também nos processos administrativos. A Lei $9.784 / 99$ prevê o amicus curiae nestes procedimentos, em casos onde houver "interesse geral".

Não obstante a importância da comparação entre o Vertreter des öffentlichen Interesses e o amicus curiae, no sentido de ampliar a aplicação desta modalidade de intervenção aos casos em que houver interesse público, devemos admitir que os dois institutos nem sempre são coincidentes. No caso do Vertreter, quando funciona nesta condição o procurador federal, sua manifestação não é livre, mas vinculada às diretrizes governamentais ("an die Weisungen der Bundesregierung gebunden"), o que é apontado em doutrina como uma característica que parcialmente o afastaria da figura do amicus curiae aqui propugnada. Todavia, o espírito empreendedor que norteou a consagração legal da figura não pode ser desmerecido e relevante é a comparação, até porque esta vinculação não existe no $\S 36$, o que faz com que o Vertreter guarde proximidade com o amicus brasileiro.

\section{Posição dos Tribunais Superiores brasileiros sobre o "amicus curiae"}

Até a presente data, poucas foram as manifestações dos Tribunais Superiores acerca da disciplina do amicus curiae. Em sua jurisprudência, todavia, já se reconheceu expressamente a importância política do instituto. De maneira geral, a abordagem do instituto cinge-se a aspectos procedimentais, como a qualificação do amigo da corte como parte ou terceiro, bem como questões de competência e sobre a possibilidade de sustentação oral durante a sessão de julgamento.

O Supremo Tribunal Federal já sufragou opinião veemente no sentido da relevância político-jurídica do amicus curiae. Ressalte-se que, no sentido do texto, o STF identifica dois fatores legitimadores da intervenção do amigo da corte: a participação política pluralista no processo e a contribuição do amicus para a decisão, trazendo elementos relevantes à apreciação da corte. No julgamento da Medida Cautelar na Adin. 2.130-SC (Relator: Min. Celso de Mello), afirma o Pretório Excelso:

“A admissão de terceiro, na condição de amicus curiae, no processo objetivo de controle normativo abstrato, qualifica-se como fator de legitimação social das decisões da Suprema Corte, enquanto Tribunal Constitucional, pois viabiliza, em obséquio ao postulado democrático, a abertura do processo de fiscalização concentrada de constitucionalidade, em ordem a permitir que nele se realize, sempre sob uma perspectiva eminentemente pluralística, a possibilidade de participação formal de entidades e de instituições que efetivamente representem os interesses gerais da coletividade ou que ex-

91 Assim, por exemplo, na França, onde se incluem as duas modalidades como "les représentants de l'intérêt général". Cf. http://www.jura.uni-sb.de/BIJUS/A340-1/, acessado em 26.10.2003. 
pressem os valores essenciais e relevantes de grupos, classes ou estratos sociais. (...) A regra inscrita no art. $7^{\circ}, \S 2^{\circ}$ da Lei ${ }^{\circ} 9.868 / 99$ - que contém a base normativa legitimadora da intervenção processual do amicus curiae - tem por objetivo pluralizar o debate constitucional, permitindo que o Supremo Tribunal Federal venha a dispor de todos os elementos informativos possíveis e necessários à resolução da controvérsia”.

Ademais, enfatiza o relator, Min. Celso de Mello, no mesmo julgamento, que é favorável à ampliação do instituto, conferindo ao amicus curiae outros poderes processuais que não apenas aqueles previstos na Lei 9.868/99:

"Presente esse contexto, entendo que a atuação processual do amicus curiae não deve limitar-se à mera apresentação de memoriais ou à prestação eventual de informações que lhe venham a ser solicitadas. Cumpre permitir-lhe, em extensão maior, o exercício de determinados poderes processuais, como aquele consistente no direito de proceder à sustentação oral das razões que justificaram a sua admissão formal na causa. (...) Tenho para mim, contudo, na linha das razões que venho de expor, que o Supremo Tribunal Federal, em assim agindo, não só garantirá maior efetividade e atribuirá maior legitimidade às suas decisões, mas, sobretudo, valorizará, sob uma perspectiva eminentemente pluralística, o sentido essencialmente democrático dessa participação processual, enriquecida pelos elementos de informação e pelo acervo de experiências que o amicus curiae poderá transmitir à Corte Constitucional, notadamente em um processo - como o de controle abstrato de constitucionalidade - cujas implicações políticas, sociais, econômicas, jurídicas e culturais são de irrecusável importância e de inquestionável significação".

Contudo, alguns poderes processuais já foram negados ao amigo da corte pelo STF. Decidiu a corte suprema que não é cabível a sustentação oral em plenário por parte do amicus curiae, ${ }^{92}$ providência que é permitida por outros tribunais, como a Suprema Corte dos Estados Unidos da América, na Rule 28 de seu regimento interno. ${ }^{93}$ O Supremo Tribunal Federal recentemente afirmou que, não obstante a

92 No julgamento da ADIn 2.321-DF, o Presidente do Tribunal, Min. Carlos Velloso, entendeu não ser possível a sustentação oral de terceiros admitidos no processo de ação direta de inconstitucionalidade na qualidade de amicus curiae. (ADInMC 2.321-DF, rel. Min. Celso de Mello, 25.10.2000). Também já foi reiterada esta decisão posteriormente, embora por maioria, no sentido de que a manifestação do amicus curiae terá de ser feita por escrito por força do art. $10 \S 2^{\circ}$ da Lei $9.868 / 99$, que prevê expressamente que, no julgamento do pedido de medida cautelar, será facultada sustentação oral aos representantes judiciais do requerente e das autoridades ou órgãos responsáveis pela expedição do ato. (ADInMC (QO) 2.223-DF, Rel. Min. Marco Aurélio, 18.10.2001).

93 Rule 28. Oral Argument. () "7. By leave of the Court, and subject to paragraph 4 of this Rule, counsel for an amicus curiae whose brief has been filed as provided in Rule 37 may argue orally on the side of a party, with the consent of that party. In the absence of consent, counsel for an 
importante função política do amicus, não se pode admitir a manifestação de muitas entidades para não haver transtornos processuais. ${ }^{94} \mathrm{Em}$ outros países, como nos EUA, este problema potencial é resolvido pela limitação da extensão das petições que o amicus curiae pode apresentar à corte, evitando divagações desnecessárias e permitindo a oitiva de um maior número de entidades.

Por outro lado, o Supremo Tribunal Federal demonstra-se vacilante na conceituação jurídica do amicus curiae, por vezes afirmando ser modalidade de intervenção de terceiros, por outras negando-lhe esta condição, ora admitindo não integrar o amicus curiae a relação processual, outras vezes afirmando sua inserção. ${ }^{95}$

Mais coerente no que tange à posição jurídica do amigo da corte, o Superior Tribunal de Justiça mantém entendimento de que o amicus não é parte, mas terceiro cujo interesse na causa é apenas indireto. Essa compreensão repercute diretamente em questões de competência ratione personae. Desta forma, tem a corte forte posicionamento pela impossibilidade de transferir para a Justiça Federal a competência das causas em que a União Federal intervém com base no art. $5^{\circ}$ da Lei 9.469/97. Nestes casos, diz o STJ, a União não é parte nem assistente, e o interesse do interveniente é apenas indireto, o que não inclui a hipótese dentro do rol taxativo do art. 109 da CR/88. ${ }^{96}$ Todavia, ainda há vozes dissonantes dentro do próprio STJ,

amicus curiae may seek leave of the Court to argue orally by a motion setting out specifically and concisely why oral argument would provide assistance to the Court not otherwise available. Such a motion will be granted only in the most extraordinary circumstances".

94 STF - Adin 2937 - Rel. Min. Cezar Peluso, despacho de 16.09.2003, disponível em http:llwww.stf.gov.br. A ação direta de inconstitucionalidade ainda não foi julgada no mérito. 95 Veja-se a contradição. Por exemplo, no Ag Rg na Adin n ${ }^{\circ}$ 748/RS (Relator:Min. Celso de Mello. Julgamento: 01.08.1994 - Tribunal Pleno), diz o relator: "O processo de controle normativo abstrato instaurado perante o Supremo Tribunal Federal não admite a intervenção assistencial de terceiros. Precedentes. Simples juntada, por linha, de peças documentais apresentadas por órgão estatal que, sem integrar a relação processual, agiu, em sede de ação direta de inconstitucionalidade, como colaborador informal da Corte (amicus curiae): situação que não configura, tecnicamente, hipótese de intervenção ad coadjuvandum". Já em outro julgamento (Medida Cautelar na Adin. 2.130-SC Relator: Min. Celso de Mello, DJU em 02.02.2001), diz o STF: "No estatuto que rege o sistema de controle normativo abstrato de constitucionalidade, $o$ ordenamento positivo brasileiro processualizou a figura do amicus curiae (Lei ${ }^{\circ} 9.868 / 99$, art. $7^{\circ}, \S 2^{\circ}$ ), permitindo que terceiros - desde que investidos de representatividade adequada — possam ser admitidos na relação processual, para efeito de manifestação sobre a questão de direito subjacente à própria controvérsia constitucional.(...) Como se sabe, o pedido de intervenção assistencial, ordinariamente, não tem cabimento em sede de ação direta de inconstitucionalidade, eis que terceiros não dispõem, em nosso sistema de direito positivo, de legitimidade para intervir no processo de controle normativo abstrato (RDA 155/155 - RDA 157/266 - Adin 575-PI (AgRg). Rel. Min. Celso de Mello). A Lei n 9.868/99, ao regular o processo de controle abstrato de constitucionalidade, prescreve que 'Não se admitirá intervenção de terceiros no processo de ação direta de inconstitucionalidade' (art. $7^{\circ}$, caput). (...) Não obstante todas essas considerações, cabe ter presente a regra inovadora constante do art. $7^{\circ} \S$ $2^{\circ}$, da Lei $n^{\circ} 9.868 / 99$, que, em caráter excepcional, abrandou o sentido absoluto da vedação pertinente à intervenção assistencial, passando, agora, a permitir o ingresso de entidade dotada de representatividade adequada no processo de controle abstrato de constitucionalidade.

96 STJ - $1^{\lrcorner}$Turma - RESP 313336-SP - Rel. Min. Milton Luiz Percira, Julg. 28.05.2001. Ementa: 
afirmando o caráter assistencial da intervenção da União Federal neste caso e a conseqüente competência da Justiça Federal, nos processos em que haja sua intervenção. ${ }^{97}$

Finalmente, têm entendido o STF e o STJ, em nosso sentir com razão, que a intervenção do amicus curiae somente poderá ocorrer durante a instrução processual, não sendo admissível depois de iniciado o julgamento. ${ }^{98}$ Sem embargo, a oitiva do amicus curiae, tanto na sua dimensão política de participação, quanto em relação ao aspecto contributivo do contraditório para a decisão, é justificável antes do ato decisório. A posição jurisprudencial externada pelo STJ, neste ponto mais detalhada, é no sentido de que a manifestação do amicus curiae deverá ocorrer no prazo de 30 dias previsto nos arts. $6^{\circ}$ e $7^{\circ} \S 2^{\circ}$ da Lei $9.868 / 99 .^{99}$

“Processual Civil. Ação de Desapropriação. Sociedade de Economia Mista (CESP). Constituição Federal, art. 109, I e VIII. Súmulas n's 517 e 556/STF e 42/STJ. 1. À Justiça Federal não compete processar e julgar Ação de Desapropriação movida por Sociedade de Economia Mista (pessoa Jurídica de Direito Privado), não elencada entre as entidades públicas mencionadas no art. 109 , VIII, Constituição Federal. 2. A intervenção da União Federal, autarquia ou empresa pública como assistente ou opoente, só deslocará a competência se demonstrado legítimo interesse jurídico próprio, ficando sem força atrativa apenas a participação ad adjuvandum. No caso, a União não manifestou qualquer interesse. A competência é da Justiça Estadual. 3. Recurso provido". Esse posicionamento também tem respaldo em outros tribunais federais. TRF $-5^{\mathrm{a}}$ Região $-1^{\mathrm{a}}$ Turma Agravo de Instrumento $n^{\circ}$ 04176-PE, Rel. Juiz Hugo Machado, Julg. 23.05.1995. Ementa: “Constitucional e Processual Civil. Sociedade de Economia Mista. Intervenção da União no feito. Lei 8.197/91. Competência. A intervenção da União no processo, nos termos do art. segundo, da Lei $8.197 / 91$, independe da demonstração de interesse jurídico, mas não torna competente a justiça federal, posto que a lei ordinária não pode ampliar o alcance da norma do art.109, inciso I, da constituição. $O$ interesse que, extrajudicialmente, é exercitado por intermédio da sociedade de economia mista, não atribui à União a condição de assistente nas causas em que aquela é parte. Agravo provido."

97 STJ - $1^{\text {a }}$ Seção - CC 34217-BA, Rel. Min. Luiz Fux, Julg. 25.09.2002. Ementa: "Conflito negativo de competência. Anulação de título dominial. Ente Federal. Interesse Jurídico. 1. A intervenção da União na causa, manifestando interesse de qualquer ordem, nos termos da novel Legislação Federal, 9.469/97, desloca a competência para o Juízo Federal ou para o Juízo que faça as suas vezes, na forma do permissivo constitucional. 2. Exegese que se reforça pelo fato de a União sofrer efeitos da sentença. 3 . As causas em que a Uniāo for interessada na condição de assistente devem ser processadas e julgadas pela Justiça Federal. 4. Conflito conhecido para declarar competente o Juízo Federal da $14^{\mathbf{2}}$ Vara da Seção Judiciária do Estado da Bahia, o suscitado".

98 ADInMC 2.238-DF, rel. Min. Ilmar Galvão, 9.5.2002.

99 STF - Adin 2937 - Rel. Min. Cezar Peluso, despacho de 16.09.2003, disponível em http:Nlwww.stf.gov.br; STJ - Segunda Turma - AgRg em Medida Cautelar 5238-RJ, julgado em 17.09.2002, Rel. Min. Laurita Vaz. "Ementa: Agravo Regimental na Medida Cautelar. Processo Civil. Representação por inconstitucionalidade. Intervenção do amicus curiae. Art. $7^{\circ} \S 2^{\circ}$, da Lei 9.868/99. Recusa do órgão julgador. Processo devidamente instruído e pronto para julgamento. Uitrapassagem do momento oportuno. Arguiição de ilegalidade. Inexistência. Pretensão de efeito suspensivo ao recurso especial. Indeferimento da liminar. Ausência dos pressupostos. Agravo Improvido. 1. Não se afigura plausível, a essa altura, o direito argüido, mormente tendo em vista a superação do momento processual oportuno para a admissão da manifestação pretendida, que é justamente o prazo inicial de trinta dias destinado à instrução do feito com a colhida das informações pertinentes". 
A mitologia grega é extremamente curiosa e fascinante, pois os deuses que eram adorados pelos gregos antigos possuíam forma e atributos humanos, detentores que eram dos mesmos defeitos, qualidades e paixões dos homens. Hermes não era perfeito e, embora tenha prometido a Zeus que não mentiria antes de obter a atribuição de mensageiro do Olimpo, em muitas aventuras posteriores é descrito como protagonista de atos ilícitos e negócios escusos, ardilosos, como no episódio em que assassinou Argos a pedido de Zeus ou quando furtou o gado do deus Apolo.

Nas sandálias de Hermes, sabemos que o amicus curiae pode trazer informações desnecessárias ou até inverídicas, movido mesmo por interesses meramente econômicos de duvidosa idoneidade. Cabe, assim, ao magistrado, estar atento à relevância da matéria trazida a lume pelo amigo da corte e, ao mesmo tempo em que permitir a participação social através do processo, não deixar que a intervenção do amicus represente um estorvo para a prestação jurisdicional, um descompasso procedimental que possa importar, por exemplo, em injustificada demora.

Cabe destacar que de toda sorte a intervenção deve ser fomentada porque o debate judicial não pode fenecer por conta de uma concepção egocêntrica da hermenêutica como tarefa estática e solitária do magistrado. Ao contrário, para que a decisão seja tão mais aperfeiçoada e legítima dentro de um contexto jurisdicional de participação popular, mister se faz que a interpretação seja enriquecida pela $\operatorname{argumentação~}^{100}$ pluralista, objetivo que vai ao encontro da ratio do amicus curiae.

Que o caduceu de Hermes, antes de adormecer os sujeitos processuais, ilumine de cores douradas o decisum, contribuindo para uma decisão melhor e ampliando a dimensão participativa do processo.

\section{Bibliografia}

ALONSO GARCIA, Enrique. La Interpretacion de la Constitucion. Madrid: Centro de Estudios Constitucionales, 1984.

ARAÚJO CINTRA, Antonio Carlos et alii. Teoria Geral do Processo. Op. Cit., p. 265.

BARACHO, José Alfredo de Oliveira. "Constituição e Processo. O modelo constitucional e a teoria geral do processo constitucional. Natureza e categoria dos princípios processuais inseridos na constituição" in Revista Forense, vol.353, janeiro-fevereiro, 2001.

BARBOSA MOREIRA, José Carlos. "Processo civil e processo penal: mão e contramão?”, in Temas de Direito Processual - $7^{\mathbf{a}}$ Série. São Paulo: Saraiva, 2001.

100 Sobre a necessidade de abertura interpretativa do Judiciário à comunidade, de forma a que sejam conciliados os fatores normativos e a realidade social, Cf. SILVA, Carlos Bruno Ferreira da. "Caracteristicas da interpretação da norma legal", mimeografado, trabalho apresentado ao Programa de Pós-Graduação em Direito da PUC-Rio, 2003. 
BAUR, Fritz e GRUNSKY, Wolfgang. Zivilprozeârecht. Kriftel: Luchterhand, 10. Auflage, 2000.

CALAMANDREI, Piero. "Processo e Democrazia" in Opere Giuridiche. Napoli: Morano Editore, vol.1.

CALMON DE PASSOS, José Joaquim. "Democracia, participação e processo", in Pellegrini, Ada et alii (Coord.) Participação e Processo. São Paulo: Revista dos Tribunais, 1988.

. "Instrumentalidade do processo e devido processo legal", in Revista Forense, vol.351, p.109.

CANOTILHO, José Joaquim Gomes. “A principialização da jurisprudência através da constituição", in Revista de Processo, vol.98. 1998.

Direito Constitucional e Teoria da Constituição, Coimbra: Almedina,

CARNEIRO, Athos Gusmão. "Mandado de Segurança - Assistência e amicus curiae", in Revista Síntese de Direito Civil e Processual Civil, n² 24, jul-ago, 2003. Intervenção de terceiros. São Paulo: Saraiva, $3^{\mathrm{a}}$ Ed., 1986.

"Da intervenção da União Federal como amicus curiae. Ilegitimidade para, nesta qualidade, requerer a suspensão dos efeitos da decisão jurisdicional. Leis $n^{\circ} 8.437 / 92$, art. $4^{\prime \prime}$ e n. 9.469/97, art.5", in Revista Forense, vol.363, setembro-outubro, 2002.

CARREIRA ALVIM, José Eduardo. Elementos de Teoria Geral do Processo. Rio de Janeiro: Forense, 1999.

CRUZ e TUCCI, José Rogério. A motivação da Sentença no Processo Civil. São Paulo: Saraiva, 1987.

DINAMARCO, Cândido Rangel. A Instrumentalidade do Processo. São Paulo: Malheiros, $9^{a}$ Ed., 2001. . Litisconsórcio. São Paulo: Malheiros, $7^{\mathrm{a}}$ Ed., 2002.

Fundamentos do Processo Civil Moderno. São Paulo: Revista dos Tribunais, $2^{\mathbf{a}}$ Ed., 1987.

HÄBERLE, Peter. Hermenêutica Constitucional. A sociedade aberta dos intérpretes da Constituição: contribuição para a interpretação pluralista e "procedimental" da Constituição. Trad. Gilmar Ferreira Mendes. Porto Alegre: Sérgio Antonio Fabris Editora, 1997.

HIRTE, Heribert. "Der amicus-curiae-brief - das amerikanische Modell und die deutschen Parallelen", in Zeitschrift für Zivilprozeâ, 104. Band, Heft 1, 1991.

JAUERNIG, Othmar. . Zivilprozessrecht. München: C.H.Beck Verlag, $28^{\mathrm{a}}$ Ed., 2003.

KUMMER, Max. Grundriss des Zivilprozessrechts. Bern: Stämpfli, 1970.

LIEBMAN, Enrico Tullio. Manual de Direito Processual Civil. Trad. Cândido Rangel Dinamarco. Rio de Janeiro: Forense, vol. I, 1984.

MACIEL, Adhemar Ferreira. "Amicus curiae: um instituto democrático", in Revista de Processo, vol.106.

MENDES, Aluisio Gonçalves de Castro. Ações coletivas no direito comparado e nacional. São Paulo: Revista dos Tribunais, 2002.

MENDES, Gilmar Ferreira. "Controle de Constitucionalidade: Hermenêutica Constitucional e Revisão de Fatos e Prognoses Legislativos pelo Órgão Judicial" in Revista dos Tribunais, vol.766, agosto, 1999. 
OLIVEIRA, Carlos Alberto Álvaro. "A garantia do contraditório" in Revista Forense, vol.346, abril-junho, 1999.

PEREIRA, Milton Luiz. "Amicus curiae - Intervenção de terceiros", in Revista de Processo, vol.109.

PINHO, Humberto Dalla Bernardina de. A natureza jurídica do direito individual homogêneo e sua tutela pelo Ministério Público como forma de acesso à justiça. Rio de Janeiro: Forense, 2002.

SILVA, Carlos Bruno Ferreira da. "Características da interpretação da norma legal”, mimeografado, trabalho apresentado ao Programa de Pós-Graduação em Direito da PUC-Rio, 2003

TARZIA, Giuseppe. " $O$ contraditório no processo executivo" in Revista de Processo, $n^{\circ} 28$, outubro-dezembro de 1982.

TESHEINER, José Maria Rosa. "Situações subjetivas e processo", in Revista de Processo, vol.107.

THEODORO JR., Humberto. Sentença. Rio de Janeiro: Aide, 1991.

TROCKER, Nicolò. "Il nuovo articolo 111 della costituizione e il 'giusto processo' in materia civile: profili generali", in Rivista trimestrale di Diritto e Procedura Civile, Anno LV, n.2, junho, 2001. 


\section{Índice Analítico da Revista de Direito Administrativo - RDA}

Vols. 140 a 186

Vols. 187 a 198

Vols. 199 a 210

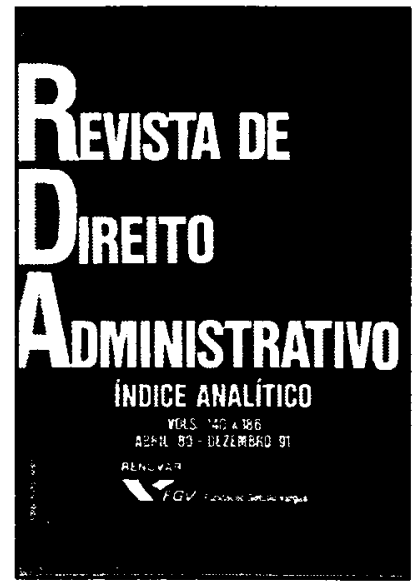

Indispensável como fonte de consulta para facilitar a localizaçāo, sem perda de tempo, dos respectivos assuntos apresentados na Revista de Direito Administrativo.

Ref. 0055

Ref. 0089

Ref. 0177

Cartonado

Form. 16x23

1991-1998

\section{Instituições Civis no Direito do Trabalho}

Alexandre Agra Belmonte

De conceitos atuais, de exemplos e com linguagem de fácil compreensão, não obstante a profundidade com que são tratados os temas estudados, trata-se de obra indispensável aos aspirantes da magistratura e procuradoria do trabalho, compreensiva de toda a matéria dos respectivos concursos, advogados, universitários, professores e todos os demais profissionais que militam na área trabalhista. O livro atenta para os fatos jurídicos, porque ele dá uma perfeita noçāo do significado e alcance da obra, bem como de sua utilizaçāo prática.

Ref. 0078

Form. 14x21
Brochura 1997
366 págs. $2^{2}$ ed.

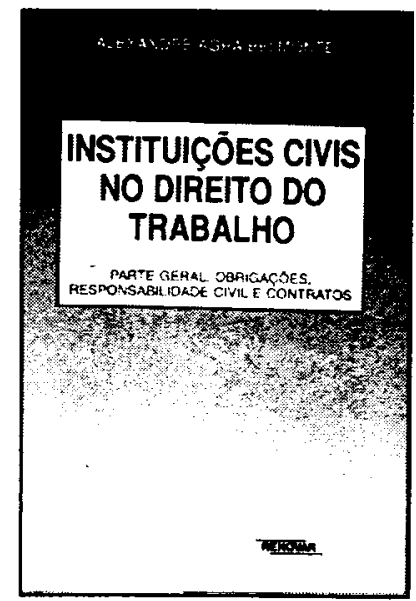

